\title{
Resolving Behavioral Output via Chemogenetic Designer Receptors Exclusively Activated by Designer Drugs
}

\author{
C. Joseph Burnett ${ }^{1,2,3}$ and Michael J. Krashes ${ }^{1,2}$ \\ ${ }^{1}$ Diabetes, Endocrinology and Obesity Branch, National Institute of Diabetes and Digestive and Kidney Diseases, National Institutes of Health, Bethesda, \\ Maryland 20892, ${ }^{2}$ National Institute on Drug Abuse, National Institutes of Health, Baltimore, Maryland 21224, and ${ }^{3}$ Brown University-National Institutes \\ of Health Graduate Partnerships Program, Providence, Rhode Island 02912
}

Designer receptors exclusively activated by designer drugs (DREADDs) have proven to be highly effective neuromodulatory tools for the investigation of neural circuits underlying behavioral outputs. They exhibit a number of advantages: they rely on cell-specific manipulations through canonical intracellular signaling pathways, they are easy and cost-effective to implement in a laboratory setting, and they are easily scalable for single-region or full-brain manipulations. On the other hand, DREADDs rely on ligand-G-protein-coupled receptor interactions, leading to coarse temporal dynamics. In this review we will provide a brief overview of DREADDs, their implementation, and the advantages and disadvantages of their use in animal systems. We also will provide numerous examples of their use across a broad variety of biomedical research fields.

Key words: behavior; cell-type specificity; chemogenetics; DREADD

\section{Introduction}

For centuries, scientists dreamed of the age they could selectively control defined cell populations to further understand the machinations of the brain and nervous system. Over time, researchers discovered neuronal contacts across the brain could be parsed based on the unique gene expression profiles of each cell type in a given brain region; this made genetic-targeting strategies a perfect entry point for investigating neural circuit function. Yet tools capable of inferring spatiotemporal modulation of explicit populations of neurons and the elaborate networks they comprise were still lacking. Over the past decades a number of approaches have been developed, optimized, and used to either drive the activity of neurons, and thus assess functional sufficiency, or to silence neurons, and thus assess their necessity. These interventional methods rely on different wavelengths of light, radio waves, and magnetic fields, as well as both endogenous and exogenous chemical actuators (Arenkiel et al., 2008; Magnus et al., 2011; Güler et al., 2012; Sternson and Roth, 2014; Deisseroth, 2015; Stanley et al., 2016; Wheeler et al., 2016). Although each technique possesses many advantages and limitations, this TechSight will focus on the most widely used class of chemogenetic tool, designer receptors exclusively activated by designer drugs (DREADDs) and their successful use in the molecular and anatomical dissection of neural circuit regulating behavior; we also

Received April 5, 2016; revised June 29, 2016; accepted July 13, 2016.

This work was supported by the Intramural Research Program of the National Institutes of Health, The National Institutes of Diabetes and Digestive and Kidney Diseases [DK075087 (M.J.K.), DK075089 (M.J.K.)]. We thank Bryan L. Roth for guidance.

The authors declare no competing financial interests.

Correspondence should be addressed to Michael J. Krashes at the above address. E-mail: michael.krashes@nih.gov.

DOI:10.1523/JNEUROSCI.1333-16.2016

Copyright $\odot 2016$ the authors $\quad 0270-6474 / 16 / 369268-15 \$ 15.00 / 0$ address their use in concert with other neuronal manipulation or monitoring techniques.

The quintessential platform for manipulating neural activity would require limited to no specialized equipment and provide noninvasive, multiplexed spatiotemporal control of molecularly circumscribed cell types ranging from single synapses to entire ensembles of neurons; chemogenetic tools meet many of these criteria. Simply stated, the chemogenetic platform requires two key components: an engineered protein designed to interact with a small-molecule chemical actuator with heightened specificity and potency. Researchers designed the first chemogenetic tools $>20$ years ago and continue to make improvements on previous generations. As templates, scientists have used a wide array of protein classes, including kinases (Bishop et al., 1998; 2000; Chen et al., 2005; Cohen et al., 2005; Dar et al., 2012; Liu et al., 1998), nonkinase enzymes (Collot et al., 2003; Häring and Distefano, 2001; Klein et al., 2005; Strobel, 1998), G-protein-coupled receptors (GPCRs; Alexander et al., 2009; Armbruster and Roth, 2005; Armbruster et al., 2007; Redfern et al., 1999; 2000; Vardy et al., 2015), and ligand-gated ion channels (Arenkiel et al., 2008; Lerchner et al., 2007; Magnus et al., 2011; Zemelman et al., 2003). While many of these receptors effectively replicated the abilities of endogenous receptors ex vivo, some demonstrated affinity to native ligands, which could have deleterious effects on physiology via ectopic signaling. Conversely, synthetic ligands often showed higher-than-desirable affinity for native receptors, leading to a collection of off-target effects. Furthermore, a number of the chemical actuators failed to cross the blood-brain barrier, eliminating peripheral administration capabilities. Thus, researchers sought a new generation of chemogenetics designed to reduce nonspecific binding of both ligands and receptors for native factors with the added capacity to pass freely into the brain from the periphery. 
The most successful-and now most extensively used-of these advances were the human muscarinic (hM) receptor-based DREADDs. These hM variants have been fashioned to signal through one of four canonical GPCR cascades: (1) $\mathrm{G}_{\mathrm{q}}$-mediated pathways that increase excitability and enhance neural firing (Alexander et al., 2009), (2) $\mathrm{G}_{\mathrm{i} / \mathrm{o}}$-mediated pathways that result in presynaptic inhibition and silencing of neural activity (Armbruster et al., 2007; Stachniak et al., 2014), (3) $\mathrm{G}_{\mathrm{s}}$-mediated pathways that have been demonstrated to increase cAMP levels and modulate plasticity (Farrell et al., 2013), and (4) $\beta$-arrestinmediated pathways that could be used to assess specific behaviors downstream of $\beta$-arrestin signaling cascades (Nakajima and Wess, 2012). Each type of hM DREADD is activated by the artificial, otherwise pharmacologically and behaviorally inert, ligand clozapine- $\mathrm{N}$-oxide (CNO). Ideal chemical actuators should have excellent drug-like properties with rapid CNS penetration and distribution, all of which are attractive properties shared by $\mathrm{CNO}$ (Bender et al., 1994). Although incidences of CNO being metabolized via back-transformation to clozapine have been reported in humans and guinea pigs (Jann et al., 1994), this has not been an issue in mice or rat studies at the low concentrations needed to activate the receptors. Nonetheless, work continues on developing new non-CNO chemical actuators, such as compound 21, eliminating this possibility entirely (Chen et al., 2015).

Current DREADD technology provides researchers with many powerful advantages. Delivery of the chemical actuator responsible for activating DREADDs can be minimally invasive: $\mathrm{CNO}$ is water-soluble and can be administered via drinking water, injected intraperitoneally, or even directly infused intracranially. CNO itself is widely commercially available and relatively inexpensive compared with specialized equipment for delivering distinct wavelengths of light, radio frequencies, or magnetic fields. Due to the simple nature of DREADDs, introduction into animal systems (see below, Implementation), routine laboratory equipment is often sufficient for applying chemogenetic techniques into any laboratory setting. As this technology relies on GPCRs, the subdomains can be modified to change their point of action, for example by targeting DREADDs specifically to axons; the chemical actuator can then be specifically infused directly to axon terminals of interest (Stachniak et al., 2014). Unlike other manipulation techniques, such as optogenetics, chemogenetics permits highly flexible scalability, allowing for manipulation of cells ranging from a small population in a discrete region to cell types distributed across the entire nervous system. DREADDs also use canonical GPCR signaling pathways, meaning almost all cell types contain the endogenous molecular machinery for these types of manipulations. Notably, most if not all DREADDs are fused or tagged to a fluorophore facilitating their anatomical detection ex vivo. Together, these advantages make DREADDs highly attractive research tools for precise investigation of neural circuits.

One unique advantage of chemogenetics is its ability to be multiplexed with many other manipulation or monitoring techniques, such as optogenetics or calcium imaging, respectively (further discussed below). Despite the creation of hM DREADDs producing opposing effects on neural activity, the ability to multiplex, that is to manipulate $\geq 2$ separate populations of neurons independently solely using DREADDs, was lacking given the common chemical actuator CNO. To address this issue, a novel DREADD based on the $\kappa$-opioid receptor as a template (KORD) was developed to respond to the inert ligand salvinorin B (SalB) with extremely high specificity and potency (Vardy et al., 2015). Like endogenous $\kappa$-opioid receptors, KORD signals through Gi- mediated pathways, and accordingly this tool has been demonstrated to acutely inhibit neural activity with shorter kinetics than the hM4Di DREADD, eliciting behavioral effects within minutes that wash out after $\sim 1 \mathrm{~h}$. Most importantly, these two variants of DREADDs are activated by discrete small-molecule actuators, permitting multiplexing capacity. These tools have been implemented in numerous ways to investigate a constellation of behaviors.

Current incarnations suffer, however, from inherent limitations. As this technique relies on a chemical actuator, systemic administration will affect all DREADD-expressing regions of the nervous system. While chemical actuators can be intracranially infused for localized action on targets of interest, diffusion of centrally targeted actuators can be challenging to tightly control, compared with, for example, focused light used for optogenetics. Thus, when using intracranial infusions of $\mathrm{CNO} / \mathrm{SalB}$, this must be taken into consideration. Beyond spatial control drawbacks, temporal kinetics of actuator activity on targets cannot be precisely controlled. This activity depends on the DREADD system used (elaboration provided below), but both the speed of the ligand in locating the target receptor and the intrinsic properties of GPCR signaling limit temporal dynamics of this system, compared with optogenetics, which delivers light directly to the cell and immediately fires an action potential through the opening of ion channels. Furthermore, while repeated infusion or chronic exposure in drinking water (Carvalho Poyraz et al., 2016) has been used, continuous exposure to ligand may desensitize these GPCRs and mitigate the effects of continuous DREADD activation. While this may be a concern, viral and transgenic expression methods express DREADDs at high levels, likely circumventing the problem of desensitization after repeated activation (for review, see Roth, 2016). Also, studies using prolonged CNO delivery have not reported difficulty with repeated activation of DREADDs (Krashes et al., 2011; Zhan et al., 2013). Finally, although DREADDs often fuse or are tagged with fluorophore tags (such as mCherry, GFP, and mCitrine), several laboratories have reported that detection of these fluorophores in their native state can prove difficult with DREADDs. Therefore, immunohistochemistry is often used to amplify signals, making it easier to visualize DREADD expression for cell counting and colocalization analyses. Furthermore, several DREADD variants also contain a human influenza hemagglutinin (HA) tag to enable detection through antibody staining. Efforts are currently underway to combat these potential pitfalls and help DREADDs achieve their ideal potential.

\section{DREADD delivery: expressing DREADDs in vivo}

Innovations in anatomical and genetic specificity afford researchers a great amount of control over the manipulation of neuronal circuits using DREADD technology. Two primary strategies have been applied to achieve explicit cell-type expression of DREADDs: transgenic mouse lines and focally targeted viral infusions; both have been used in multiple ways with tremendous success. These approaches generally rely on either celltype-specific promoters or Cre/Lox recombination technology to attain faithful expression of exogenous DREADDs. Several transgenic mouse lines have been engineered to encode DREADDs either in distinct populations using defined promoters, as in D2-dopamine (DA) receptor-expressing striatopallidal medium spiny neurons (Farrell et al., 2013) or pancreatic $\beta$ cells (Guettier et al., 2009), indirectly under the inducible and reversible control of the transcriptional tet-on/off system (Alexander et al., 2009), or in a CAG promoter-driven/Cre recombinase-inducible man- 

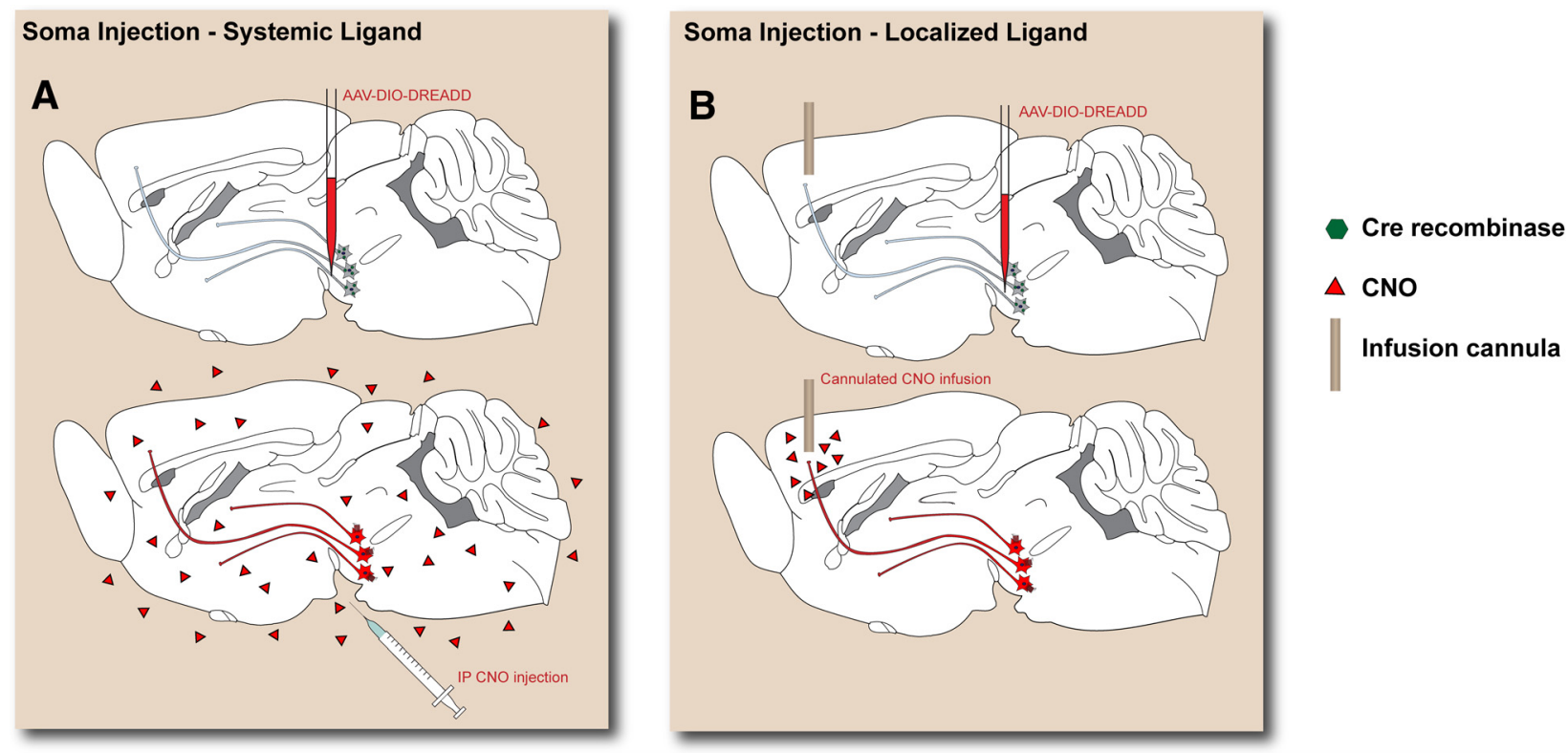

Projection-Specific Expression - Systemic Ligand
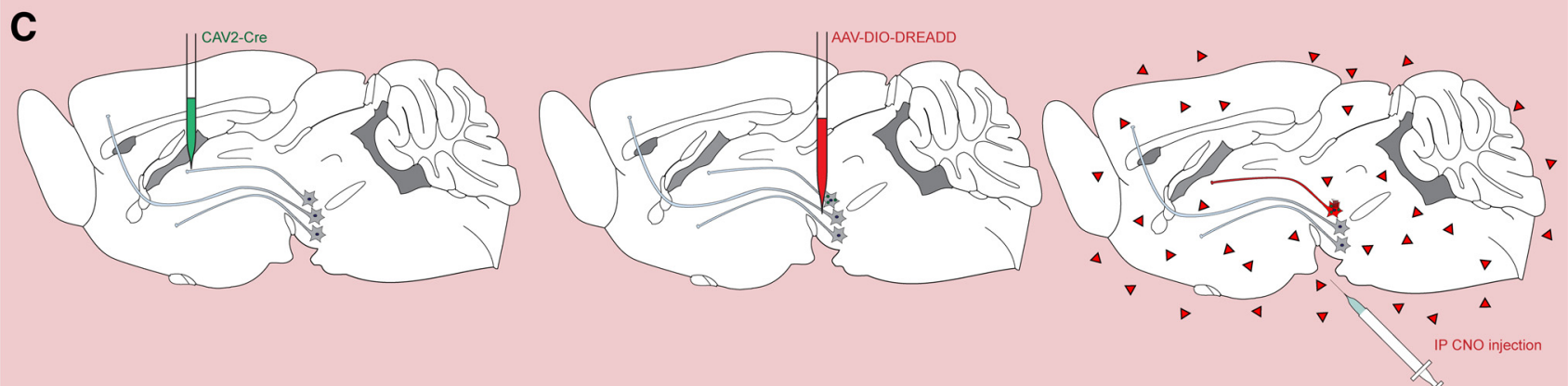

Figure 1. DREADD/ligand delivery methods in vivo. A, Systemic ligand administration. DREADDs are expressed Cre-dependently via virus (as shown) or via transgenic methods. Intraperitoneal injection of CNO will manipulate activity of only cells expressing the DREADD. B, Localized ligand administration. Alternatively, once DREADDs are expressed, an infusion cannula can be implanted over a downstream region of choice; $\mathrm{CNO}$ can be infused at this point to affect only downstream targets of a selected projection. C, Using retrogradely transporting viruses to express Cre, subsequent Cre-dependent AAV-DREADD injection at cell bodies will only affect cells projecting to the Cre virus injection site. Subsequent intraperitoneal CNO injection will only affect this projection.

ner through a knock-in scheme directed to the Gt(ROSA)26Sor locus (Steculorum et al., 2016; Roth, 2016; Zhu et al., 2016). Additional DREADD transgenic mouse lines have been developed offering intersectional genetic faculty adding such elements as a Flpe-recombination requirement in addition to Cre-dependent recombination (Ray et al., 2011). Thus, while both Cre and Flp could be expressed based on two different markers with broad expression across the brain, DREADDs would only be expressed in the cells expressing both markers, making investigation of more specific subpopulations of neurons of interest possible. Some groups have even used a Fos-based transgenic approach to introduce DREADDs into neurons naturally activated by sensory experience (Garner et al., 2012).

Transgenic lines offer identical expression levels of DREADDs in cell types of interest across all animals, providing strong control for between-mouse variability. Furthermore, unlike viral strategies in which replication is continuous, stable expression of DREADDs through transgenic approaches should result in a fixed receptor number. On the other hand, transgenic lines require breeding and maintenance of an expanded mouse colony, which can be expensive, making low-yield experiments disproportionately costly. Furthermore, each promoter-driven line can only express DREADDs in one cell type based on the promoter placed before the DREADD sequence. Lines carrying Credependent reporter alleles, such as the ROSA conditional allele, will also express DREADD in all cells marked by Cre. This approach sacrifices region-specific DREADD manipulation but can certainly prove helpful for manipulating neurons of a certain cell type across the brain (Teissier et al., 2015).

On the other hand, researchers may use viral vectors to express DREADDs in brain regions of interest. These viruses are often directed to a targeted region using premapped stereotactic coordinates determined from an atlas or database. The diffusion of the virus is dependent on several criteria, including the origin, polarity, serotype, and tropism for target cell types, as well as the titer, volume, and even method of virus delivery. While a number of variants have been broadly applied throughout the scientific community, the most commonly used version is the nontoxic adeno-associated virus (AAV) that contains two independent sets of loxP sites for Cre-dependent recombination of the vector, allowing for expression of the DREADD only in Cre-positive neurons (Atasoy et al., 2008). AAV-DREADD viral vectors are always targeted to the soma of cell types of interest where the machinery necessary for their replication and subsequent expression is localized (Fig. $1 A, B$ ). The retrogradely trafficking modified herpes simplex virus (HSV) has also proven effective at transducing 
neuron populations of interest and achieving Cre-dependent DREADD expression (Ferguson et al., 2011). Selective expression can be achieved using Cre-driven transgenic or knock-in animal lines, or through the administration of a second virus-driving expression of Cre-recombinase. This Cre-recombination virus is often another AAV, which is also injected at the soma level. Sometimes, however, projection-specific manipulations have been achieved by injection of HSV or canine adeno virus (CAV2), both of which travel in retrograde after transduction, at terminal regions of interest. Cre-dependent DREADD can then be injected at the soma as usual, but will express in projection-selective cell populations (Carter et al., 2013; Fig. 1C). Thus, these viral approaches offer several options for selectively marking subpopulations of cells with DREADDs.

Virally mediated DREADD delivery methods afford a number of advantages compared with transgenic mouse lines. First and foremost, this approach does not necessitate the often-laborious effort of generating a novel mouse line. Second, viral methods work well in nongenetically tractable organisms, such as rats and nonhuman primates, in addition to mice and flies. Just like transgenic approaches, viruses can drive expression of DREADDs from a tissue-specific promoter, such as CAMKII or GFAP, or use site-specific recombinase technologies, like Cre/Lox or Flpe/FRT. Virally mediated transduction of DREADDs allows for temporal control over the recombination process, ensuring that receptors do not interfere with any crucial developmental processes. Most critically, viral delivery methods provide tremendous spatial resolution as the experimenter has complete control over the anatomical location of DREADD expression.

Beyond these advantages, however, certain caveats need to be taken into account. Primarily, viruses do not allow for absolute control of copy number or transduction rate, as each batch of virus has a different titer and diffusion rate, as well as potential tropism limitations in the particular cell type of interest. More specifically, while viruses diffuse from the site of injection, density of virus particles will be highest at the injection site, possibly providing an unequal distribution and subsequent transduction of cells surrounding the injection site. Furthermore, the relative amount of viral particles in each individual neuron will continue to increase over time given the replication efficiency of viruses. Importantly, the actual number of neurons (even with Cre-dependent control) will vary, often drastically, between animals treated in an identical manner (same genotype, stereotactic coordinates, virus, volume, delivery methods, etc.), thus complicating the task of making precise post hoc histological analyses vital in determining the exact location of DREADD expression and the relative number of cells transduced (Atasoy et al., 2012). However, in transgenic animals, genetic-mediated expression of DREADDs should be indistinguishable between animals, thus eliminating these between-subject issues.

Once DREADDs are successfully expressed in a cell population of choice, verification of CNO-mediated DREADD activation or inhibition beyond an observed behavioral readout is of great importance in ascertaining the ability of these tools to influence the electrical activity of neurons. Validation of DREADD function has been determined using four distinct methods, with the first two being the most frequently used approaches: (1) ex vivo acute brain slice electrophysiology (Alexander et al., 2009; Krashes et al., 2011), (2) immunohistochemistry for the early immediate gene fos, a molecular correlate of neural activity (Krashes et al., 2011), (3) in vivo multielectrode arrays to monitor both local field potentials and spike activity of multiple individual neurons (Alexander et al., 2009), and (4) fiber photometry to record bulk fluorescent changes based on genetically encoded calcium indicators (Steculorum et al., 2016). According to all relevant reports we have seen, $\mathrm{CNO}$ applications have consistently depolarized or hyperpolarized $\mathrm{hM} 3 \mathrm{D}_{\mathrm{q}}$-expressing or $\mathrm{hM} 4 \mathrm{D}_{\mathrm{i}}$-expressing cells in slices or have significantly altered levels of Fos protein.

Once expression and function are verified in cell types of choice, infusion of $\mathrm{CNO}$ can occur at several different locations. The drug can be delivered intraperitoneally due to its high bloodbrain barrier permeability (Fig. 1A). Intracranial infusion can also be directed at any site of interest in the brain through a cannula. For example, if DREADD is expressed broadly across the brain, $\mathrm{CNO}$ can be guided to a specific region of interest (Fig. 1B). Using this technique, researchers have demonstrated that $\mathrm{CNO}$ can act specifically at terminals to enable or silence neurotransmission to one particular projection field (Mahler et al., 2014; Stachniak et al., 2014; Wang et al., 2015). For prolonged, persistent DREADD-mediated manipulations, CNO can be delivered directly in an animal's drinking water. This approach has the added benefit of nominal intrusiveness as experimental handling is eliminated from the administration method; the exact volume, concentration, and timing of $\mathrm{CNO}$ delivery, however, are less precise.

Regardless of expression method or ligand delivery system, perhaps the greatest boon to the application of chemogenetic techniques is their ability to be adapted to multiple experimental designs. The development of the KORD can be multiplexed with excitatory $\mathrm{hM} 3 \mathrm{D}_{\mathrm{q}}$ to allow for excitatory or inhibitory control of the same cell population (Vardy et al., 2015; Fig. 2A,B). Furthermore, these tools can be used in tandem to cells upstream or downstream from one another to assess circuit dynamics in a population of interest (Fig. 2C,D). Similarly, chemogenetic methods can be combined with optogenetic methods to alternately excite or inhibit moleculary-defined cell types (Fig. 2E,F). Finally, recent advances in real-time monitoring of neural activity using electrodes or imaging methodologies can be multiplexed with DREADD technology to determine the in vivo effects of CNO-mediated activation or silencing of activity (Steculorum et al., 2016) or alternatively can be used to assess the effects this manipulation may have on potential downstream regions.

\section{DREADDs in action}

Given the exceptional flexibility of these tools to discriminately label limitless cell types and acutely, remotely, and reversibly modulate their activity, thousands of publications have taken advantage of their efficiency and reliability to assign relative behavioral and phenotypical roles of anatomically and/or molecularly explicit populations of cells. These roles range from those having to do with energy homeostasis, depression, anxiety, and social behavior to those related to reward and memory. Below we have highlighted specific examples of general methods of isolating certain cell populations for subsequent manipulations. Given both the multitude of studies and persistent properties of DREADDs to influence behaviors over time, we end this section with an overview of homeostatic energy balance as a case study of the myriad uses for DREADDs and their combination with other methods to advance a specific field of neuroscience.

\section{Region-specific manipulations}

Individual brain regions

Using the viral delivery methods reviewed above, DREADDs can be delivered to discrete brain regions for highly specific, reversible anatomical control over neural activity in these sites (Fig. $3 A)$. Inhibitory DREADDs have proven particularly indispen- 

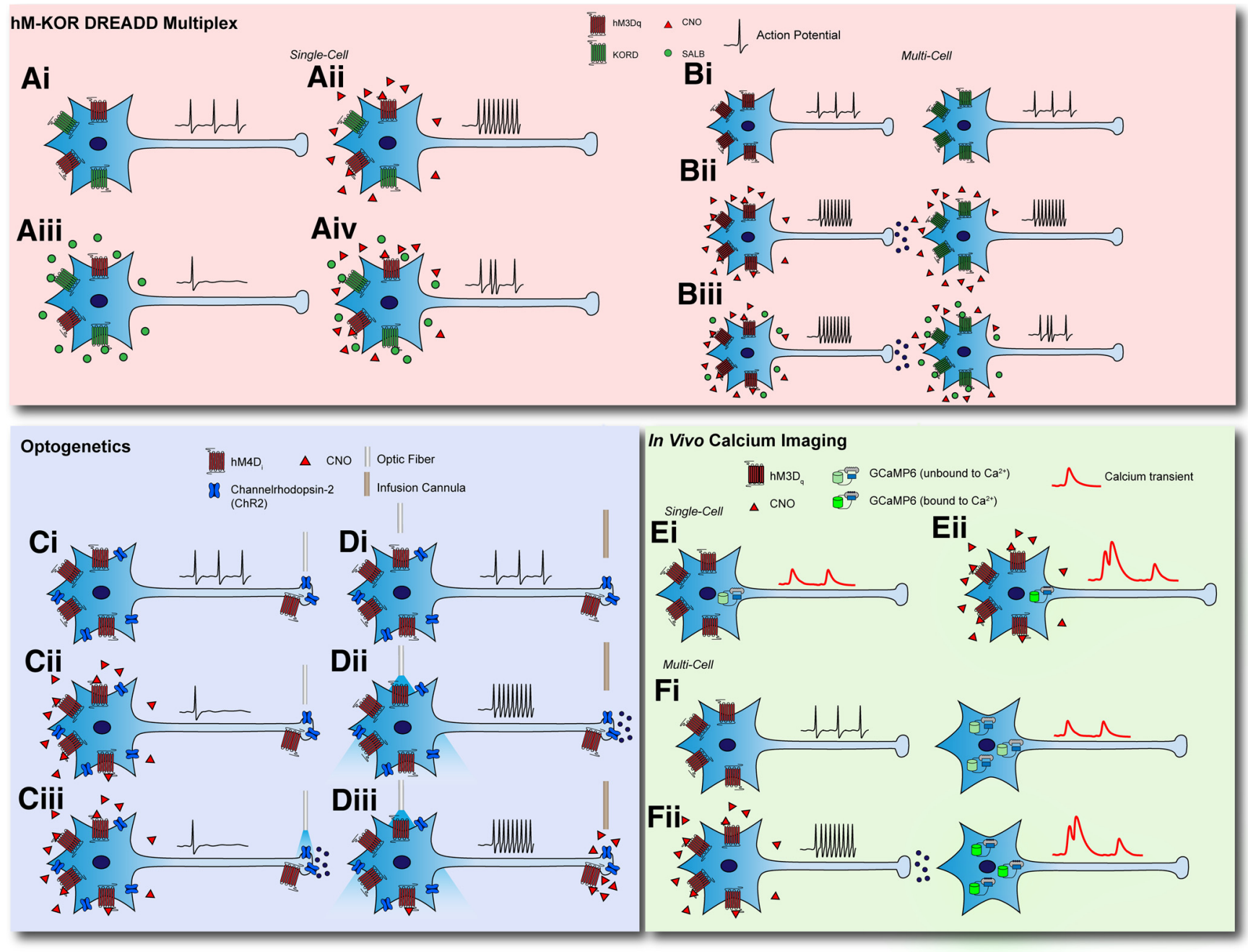

Figure 2. DREADD multiplexing opportunities. $\boldsymbol{A}$, Excitatory hM DREADDs can be expressed with inhibitory KOR DREADDs in the same cell type (Ai). Administering CNO will increase activity in these cells (Aii) while SalB administration will decrease activity (Aiii). Coadministration will produce an occlusion of excitation and inhibition, producing blunted change in neural activity (Aiv). $B$, Alternatively, excitatory hM DREADD can be expressed upstream of a presumptively connected circuit while KOR DREADDs are expressed postsynaptically. In this example, the presynaptic neurons are excitatory (Bi). Administration of CNO will increase activity both in the hM-expressing population and the presumptive downstream population (Bii), while coadministration of both ligands will occlude the presynaptic excitatory drive from the CNO-expressing population (Biii). C, D, Likewise, opsins and DREADDs can also be expressed in the same cell population. For example, inhibitory DREADD and channelrhodopsin-2 can be expressed in one population, and an optic fiber can be positioned over a specific terminal field (Ci) or over the cell body with an infusion cannula at a specific terminal field (Di). Systemic CNO administration will decrease cell firing rate (Cii), but optogenetic terminal stimulation can elicit synaptic release despite broader hyperpolarization of the cell (Ciii). On the other hand, optogenetic soma stimulation will increase cell activity (Dii), but this can be occluded using cannulated infusion of CN0 at terminal fields (Diii). E, $F$, To monitor cell activity changes in real time, DREADDs can also be multiplexed with fluorophores such as GCaMP. These can be expressed in the same cell (Ei) or expressed in series (Fi). Systemic administration of CNO can activate DREADDs, producing a change in intracellular calcium, thus altering GCaMP signals; for example, excitatory DREADD activation produces large increases in calcium activity (Eii). Moreover, when excitatory DREADD is expressed in presynaptic populations and GCaMP is expressed in a postsynaptic population, systemic CNO administration would produce increases in calcium activity in the postsynaptic cell, leading to an increased GCaMP signal (Fii).

sible in determining the necessity of certain anatomical nodes in certain neuronal functions, serving as a mutable proxy for classical brain-lesion techniques. DREADDs were used to demonstrate that serotonin (5-HT)-deficient mouse models were especially sensitive to social-defeat stress, but that explicit inhibition of the lateral habenula (LHb), a region implicated in treatmentresistant depression, blocked the development of social-defeat stress (Sachs et al., 2015). Broad chemogenetic inhibition of the $\mathrm{LHb}$ also reduced expression of depression-related behaviors in rats (Nair et al., 2013). Using rodent models of binge drinking, pan-neuronal suppression of the nucleus accumbens (NAc), part of the very large striatum region, robustly suppressed alcohol consumption while leaving consumption of other substances, including sucrose or water, as well as locomotor activity, unaffected (Cassataro et al., 2014). A downstream region of the striatum, the ventral pallidum (VP), seems particularly important for the phenomenon of sign tracking, in which a reward-associated cue takes on the rewarding properties of its matched stimulus. DREADDmediated inhibition of this structure specifically decreased motivated behavior to pursue a cue previously associated with a reward (Chang et al., 2015). The VP has also been associated with addiction-related learning changes. Using DREADDs to acutely inhibit the VP, a cue-induced reinstatement of cocaine seeking via a circuit emanating from the rostal VP was identified that affected dopaminergic signaling from the ventral tegmental area (VTA) while a separate pathway from caudal VP neurons influenced cocaine-primed drug seeking (Mahler et al., 2014). Inhibition of the bed nucleus of the stria terminalis (BNST) blocked cue-driven alcohol seeking as probed in a conditioned place-preference assay when DREADDs were 


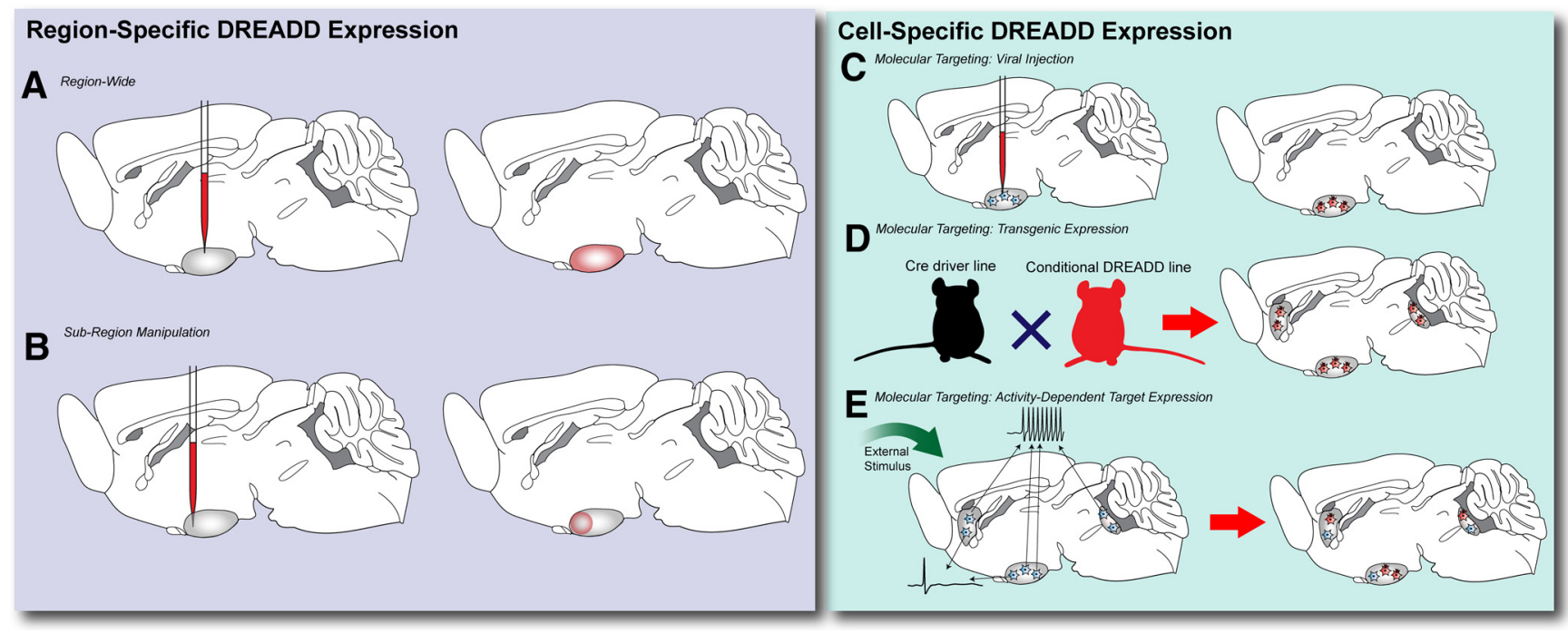

Figure 3. Common DREADD targeting strategies. A, Promoter-driven DREADD can be directed to a region of interest and expressed with anatomical precision. Subsequent CNO administration will cause changes in neural activity across the whole structure. $B$, This can be further titrated by limiting the volume of a viral injection and directing it to a specific subregion of an area of interest. CNO administration will then affect this smaller, better defined area. $\boldsymbol{C}$, By using a Cre driver line, viruses can be injected into regions of interest and only affect specific cellular subtypes of interest. $\boldsymbol{D}$, This can also be accomplished using conditional transgenic mouse lines, but these lines will affect all Cre-expressing cells lacking spatial dynamics. $\boldsymbol{E}$, DREADD expression resulting from increased endogenous neural activity to a particular stimulus using a fos-based transgenic approach.

used to suppress this structure's activity during a preference test (Pina et al., 2015).

Using excitatory DREADDs, researchers have demonstrated the sufficiency of specific brain regions to influence various brain processes. In this way DREADDs serve as a flexible proxy for classical electrical stimulation techniques. One group took advantage of excitatory DREADDs' different G-protein-mediated signaling pathways to investigate the primary hub of internal clock maintenance, the suprachiasmatic nucleus (SCN), which features rhythmic expression of genes and cycling levels of cellular signals (Mohawk and Takahashi, 2011). DREADD-mediated activation of neuron populations in the SCN uncovered specific G-protein-mediated signaling pathways underlying some of these rhythmic patterns (Brancaccio et al., 2013). This was also demonstrated in the basolateral amygdala (BLA), where $\mathrm{G} \alpha_{\mathrm{s}}$ coupled DREADDs were used to demonstrate that $\mathrm{G} \alpha_{\mathrm{s}}$ proteinmediated signaling could produce acute anxiety-like behavior and induce social anxiety-like behavior (Siuda et al., 2016).

DREADD expression can also be constricted to individual anatomical connections from one brain area to another. Selective inhibition of the orbitofrontal cortex (OFC) to such targets as the BLA (in rodents; Zimmermann et al., 2015) or the rhinal cortex (in nonhuman primates; Eldridge et al., 2016) reduced performance in reward-oriented decision-making tasks, rendering previous learning ineffective. This technique has also proven fruitful for explaining psychiatric treatment with glutamatergic NMDA receptor antagonists, such as ketamine, which produce antidepressant effects through an as-yet-to-be-determined mechanism (Berman et al., 2000; Autry et al., 2011). Chemogenetic activation of a ventral hippocampus to medial prefrontal cortex projection produced antidepressant effects to the same extent as ketamine, suggesting subanesthetic doses of this drug may affect this pathway, among others (Carreno et al., 2015). Long-term potentiation, a marker of strengthened synaptic engagement within a circuit, can also be manipulated by increasing or decreasing neuronal excitability in a presynaptic population. This has been demonstrated using DREADDs in the ventral hippocampus (Zhu et al., 2014) and the BLA (Li and Rainnie, 2014; Fig. 1C).
Subregions of brain areas

DREADDs have also been used to effectively probe the functions of specific nodes of brain structures with many subregions or subnuclei (Fig. 3B). The various regions of the cerebral cortex have been surveyed for specific involvement in a variety of functions. A recent study suggests the medial prefrontal cortex may regulate motivated responding for reward without altering reward value. DREADD-mediated activation of this region's pyramidal neurons produced an increase in operant responding for reward without affecting unconditioned food intake, social interaction, or other motivated behaviors (Warthen et al., 2016). In a recent study in mouse models of alcoholism, DREADDmediated inactivation of the lateral OFC increased ethanol drinking in alcohol-dependent mice, while nondependent mice were unaffected by this inactivation (den Hartog et al., 2016). Selective inhibition of another cortical region, the insular cortex, in methamphetamine-addicted rats reversed risk-taking behavior from greater high-risk/high-reward decision making to naive-rat levels of risk/reward decision making (Mizoguchi et al., 2015). DREADDs have also been used to causally implicate the dorsomedial prefrontal cortex in prediction error during fear learning: when this region was chemogentically activated, learning about a shock-predicting cue was not blunted by previous exposure to another predictive cue presented concurrently with the new cue (Yau and McNally, 2015). Research using DREADDs has also critically demonstrated the importance of the retrosplenial cortex in binding of sensory information to episodic memories: if this region was silenced acutely during preconditioning trials, generalization across learned sensory cues no longer occurred (Robinson et al., 2014). This has even clarified the role of the cortex in human brain conditions, such as in a mouse model for Alzheimer's disease, where intermittent inhibition of DREADD-expressing cortical neurons slowed deposits of $A \beta$ proteins while excitation of neurons in the same region increased the rate of deposition (Yuan and Grutzendler, 2016).

Several other subcortical regions also prove suitable substrates for DREADD-mediated investigation. One region to particularly 
benefit from this anatomical parsing is the amygdala, which is made up of over a dozen distinct nuclei. When fear-related memories are formed, baseline neuronal excitability seems to bias amygdala neurons toward recruitment to forming fear-related memories. To test this, one group used chemogenetic activation of lateral amygdala neurons during fear conditioning in a certain context; this facilitated expression of fear-related behavior in a subsequent exposure to the same context without chemogenetic stimulation (Yiu et al., 2014). Meanwhile, another group found that specific excitation of the BLA blocked rats' ability to suppress learning about stimuli carrying no predictive valence about fearful stimuli, suggesting that some neuropsychiatric disorder symptoms may relate to an overactive amygdala (Sengupta et al., 2016). Another brain site to benefit from this fine-grained analysis is the hippocampus. One group demonstrated that DREADD-mediated deactivation of the ventral hippocampus after fear conditioning blocked expression of fear-related behavior in the conditioned context, suggesting that the long-term memory had not been formed (Zhu et al., 2014). DREADDs were used to bidirectionally control dorsal cornu ammonis-1 (CA1) activity during the formation of object-oriented memories, which are hippocampal-dependent. Upon testing, mice with enhanced or inhibited CA1 activity during learning demonstrated facilitated or inhibited, respectively, long-term memory formation for object locations (López et al., 2016). Meanwhile, object-recognition memory formation was unaffected by manipulating this region.

Even within certain regions of the brain, function can be heterogeneous across an entire structure; localized DREADD delivery can help to dissect the specific workings of these different subregions. For example the ventromedial hypothalamus (VMH) has been implicated in a complex variety of social-interaction behaviors, putatively regulating both aggressive and mating behaviors. Interestingly, specific silencing of ventrolateral or dorsomedial compartments of this nucleus seems to independently regulate defensive behaviors in response to a predator or aggressive conspecific, respectively (Silva et al., 2013). Another region with functional heterogeneity, the striatum, also seems to contain anatomically distinct regions that regulate different aspects of behavior. DREADD-mediated alteration specifically of dorsomedial striatal direct-pathway neuron activity does not affect performance on a reward-based task, but does influence animals' ability to retain information about this task upon follow-up testing, suggesting this population is not vital for short-term task learning but rather for longer-term consolidation of rewardrelated learning (Ferguson et al., 2013). A primary cortical locus of attention regulation is the anterior cingulate cortex (ACC). Chemogenetic inhibition of the dorsal ACC escalated the omission of correct choices as well as response time to attention tasks without affecting other types of behavior or neural processing (Koike et al., 2016). By targeting DREADD expression to very specific portions of individual brain areas, highly specific function parsing is made possible.

\section{Cell-specific manipulations}

Neuronal subtypes

By far the most common use of DREADD technology has been the use of cell-specific manipulation of neural activity. Several genetic markers have been used to conduct DREADD-mediated activation or inhibition experiments in specific neuron populations (Fig. $3 C, D$ ). Many of these manipulations are targeted to neurons releasing a certain type of signaling molecule. DA signaling, for example, is integral to reward learning and reinforcement, and dysregulation of its function can lead to anhedonia and depression-like behaviors and cognitions. In one model of this phenomenon, DREADD-mediated rescue of reduced DA release reversed depression-like behaviors (Zhong et al., 2014) by targeting cells expressing the DA transporter, DAT. Likewise, DA production was rescued in the VTA in a model deficient in DA synthesis by substituting intracellular signaling mechanisms via

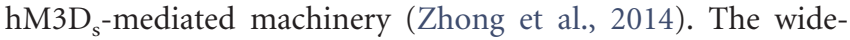
projecting norepinephrine system has also benefitted from specific DREADD targeting and manipulations. For example, altered norepinephrine signaling seems to be a hallmark of Alzheimer's disease and its comorbidity with Down syndrome. Researchers targeted DREADD using a cis-regulatory element of norepinephrine as a promoter (Hwang et al., 2001) to drive norepinephrine neuron activity in the locus ceruleus (LC). Acute activation of these neurons rescued a rodent model of Down syndrome from hyperactivity and memory-loss phenotypes (Fortress et al., 2015). Norepinephrine release from the LC is also thought to promote alert wakefulness (Aston-Jones et al., 1999). Specific DREADD-mediated activation of this LC population decreased $\delta$ power, a brainwave pattern associated with deep sleep or loss of consciousness, while elevating $\theta$ power, associated with attentive wakefulness, while rodents were under isoflurane anesthesia; this activation also promoted accelerated return to consciousness after removal of the anesthesia (Vazey and Aston-Jones, 2014).

One frequent target population is the 5-HT signaling system originating in the raphe nuclei; this population is of particular interest in the study of affective behaviors. Acute DREADDmediated activation of 5-HT neurons of the dorsal raphe nucleus (DR) facilitated expression of anxiety-like behaviors but suppressed depression-like behavior; meanwhile, chronic CNO administration did not affect anxiety-like behavior but continued to alleviate depression-like behaviors, implying a temporal resolution to serotonergic impact on affective state (Urban et al., 2016). Further parsing out the anatomy of serotonergic neural function using a combination of Cre-driver and Flpe-driver lines, it was reported that $\mathrm{DR}^{5-\mathrm{HT}}$ exerted stronger developmental effects on anxiety-related behavior, while 5-HT neurons of the medial raphe more potently affected depression-like behaviors (Teissier et al., 2015; Fig. 3D). 5-HT has also specifically been implicated in the development of social-defeat stress. Interestingly, altered 5-HT signaling in cocaine-addiction states also related to comorbid depression. Specific activation of a $\mathrm{DR}^{5-\mathrm{HT}}$ projection to the NAc simultaneously blocked cocaine-seeking behavior and the expression of depression-related behaviors (You et al., 2016). 5-HT's role in other crucial functions has also been investigated using DREADDs. As a demonstrative example, inhibitory DREADDs were used to demonstrate the necessity of 5-HT neurotransmission for homeostatic regulation of breathing responses to increased $\mathrm{CO}_{2}$ (Ray et al., 2011). Modification of this system allowed for intersectional Cre-mediated and Flp-mediated recombination of DREADDs to investigate specific subtypes of serotonergic neurons regulating $\mathrm{CO}_{2}$-mediated acidosis (Brust et al., 2014).

Signaling molecule targets may also be neuropeptides, which in and of themselves provide a genetic target for directed DREADD expression. One of these neuropeptides, oxytocin (Oxt), is downregulated in certain rodent models of autism spectrum disorders. DREADD-driven excitation of Oxt-expressing neurons in the paraventricular hypothalamus $(\mathrm{PVH})$, however, rescued social behavioral deficits of this model (Peñagarikano et al., 2015). Further investigation into this circuit using DREADDs to stimulate activity in $\mathrm{PVH}^{\mathrm{Oxt}}$ neurons suggests this population conveys information about the rewarding properties of social interaction through a cannabinoid-mediated signaling mechanism in the NAc (Wei et al., 
2015). Expression of prodynorphin (Pdyn), an endogenous opioid signaling molecule, was shown to decrease in negative affective states, particularly in the periamygdaloid cortex (Anderson et al., 2013). Acute chemogenetic inhibition of periamygdaloid cortical $^{\text {Pdyn }}$ neurons produced biomarkers and behaviors resembling negative affective states, corroborating previous findings about this system's role in depression-like states (Anderson et al., 2013).

Neurotransmitter and neuropeptide receptors also provide reasonable targets of interest, particularly if the researcher wishes to manipulate circuit nodes downstream from a signaling molecule source. For example, the striatum is a large, highly complicated region within the basal ganglia subject to dense modulation by DA; this region is thought to govern decision-making neural computations (MacPherson et al., 2014). Decisions to mate, for example, seem to be influenced by specific initiation of G-protein-mediated signaling pathways that oppositely regulate the two primary output neuron populations of this region, each expressing a different DA receptor: the D1-expressing direct-pathway neurons and D2-expressing indirect-pathway neurons (Goto et al., 2015). One group has also used DREADDs in these two populations to inhibit innate activity in direct-pathway and indirect-pathway neurons in the striatum. Silencing these two neuron populations restricted or promoted, respectively, excitatory synapses onto the basal ganglia during development (Kozorovitskiy et al., 2012). Furthermore, chemogenetic inhibition of indirect-pathway neurons of the NAc increased cocaine self-administration in rodent models (Bock et al., 2013). As neuropeptide-Y (NPY) signaling in the BNST may influence addiction states, researchers targeted DREADD expression to NPY-receptor-expressing cells in the BNST; manipulation of these cells' activity levels replicated acute activation studies suppressing binge-drinking episodes in a rodent model for binge-drinking behavior patterns (Pleil et al., 2015).

A broad array of studies have investigated interneuron populations expressing unique genetic markers; two of the most popular, parvalbumin (PV) and somatostatin (SST), have been used to study interneuron populations across a broad variety of brain areas. One recent study implicated dentate gyrus PV-expressing interneurons in the control of various behaviors: acute activation of these neurons facilitated extinction of conditioned fear-related behaviors as well as diminished anxiety-related behaviors and novel social-interaction behaviors (Zou et al., 2016). DREADDmediated suppression of PV interneurons in the prefrontal cortex facilitated expression of learned helplessness behavior in a fear-conditioning paradigm, particularly implicating this neuron population in buffering responses to fearful stimuli (Perova et al., 2015). On the other hand, acute chemogenetic silencing of SST-expressing interneurons in the frontal cortex enhanced anxiety-related behavior expression; interestingly, chronic DREADD-mediated inhibition or complete ablation of these neurons attenuated anxiety-related behavior expression, suggesting this population exerts temporally sensitive effects on affective behavior (Soumier and Sibille, 2014). In the amygdala, synapses strengthen connections onto SST-expressing neurons in the lateral portion of the central amygdala (CeA) during normal development of conditioned fear. Chemogenetic inhibition of $\mathrm{CeA}^{\mathrm{SST}}$ cells during conditioning, however, prevented the development of fear-conditioned responses, implicating their necessity for fear learning (H. Li et al., 2013).

Researchers have even used conditional gene-expression patterns to spatially or temporally control the onset of DREADD expression in highly specific cell types based on activity patterns or unique physiology (Fig. 3E). One study expressed stimulatory DREADDs in a time-controlled manner using a transgenic
c-Fos promoter-driven DREADD under control of the tettransactivator system. This system was used to monitor cell activity across the brain during exposure to a nonfear-conditioned context. Freezing behavior, which is associated with fear learning, greatly decreased upon selective activation of these cells in a fearconditioned context, suggesting activation of the ensemble of neurons forming the nonfear-conditioned memory (Garner et al., 2012). In one intriguing example of developmentally induced molecular-pathway changes, heterotopias, disorders of neuronal migration during embryonic development, were ectopically induced in regions of mouse somatosensory and prefrontal cortices (Ishii et al., 2015). These ectopic heterotopias in these regions produced principal neurons that were less responsive and improperly located. Heterotopias of this sort typically increase seizure incidence and alter social behavior and memory-task performance. Behavioral abnormalities in these heterotopia models, however, were rescued by DREADD-mediated activation of the ectopically migrated neurons (Ishii et al., 2015).

\section{Non-neuronal use of DREADDs}

Due to their ability to prompt G-protein-coupled intracellular signaling, DREADDs also serve as useful tools for investigating the function of non-neuronal cell types that support the nervous system. Astrocytes, glial cells thought to play mainly a support role for neurons of the CNS, may play more complicated roles in a number of brain functions than previously appreciated. DREADDs have been used to replicate $\mathrm{G} \alpha_{\mathrm{s}}$-mediated signaling in astrocytes and were found to impact long-term memory (Orr et al., 2015). Increased DREADD-mediated activation of astrocytes in the NAc core decreased self-administration of alcohol (Bull et al., 2014) and cocaine (Scofield et al., 2015) in rodents, implicating altered glial function in addiction states. DREADDs expressed in glial cells may even influence other organ systems. For instance, activating $\mathrm{hM} 3 \mathrm{D}_{\mathrm{q}}$ receptors in intestinal glial cells produced $\mathrm{Ca}^{2+}$-dependent colonic migrating motor complex responses, highlighting that neuroglial interactions with organs outside the nervous system exhibit similar complexity to intranervous system neuroglial interactions (McClain et al., 2015).

DREADDs have even been used to manipulate cell signaling in tissue entirely outside the nervous system. Researchers recently investigated the role of $\mathrm{G} \alpha$ signaling in liver hepatocytes, an area less well described than $\mathrm{G} \alpha_{\mathrm{s}}$-mediated signaling in these cells through GPCRs, such as glucagon receptors (J.H. Li et al., 2013). Details of $\mathrm{G} \alpha_{\mathrm{q}}$ and $\mathrm{G} \alpha$ signaling in pancreatic $\beta$ cells also proved difficult to resolve until the selective expression of DREADDs in these cells to manipulate their intracellular signaling dynamics; further providing evidence of these cells' ability to influence obese or diabetic states (Guettier et al., 2009; Jain et al., 2013). Researchers also recently targeted expression of $\mathrm{hM}_{3} \mathrm{D}_{\mathrm{q}}$ to cardiac cells; subsequent activation of these receptors induced massive arrhythmias, suggesting $\mathrm{G}_{\mathrm{q}}$ signaling in the heart may exert control of cardiac rhythms where previously this role could not be demonstrated (Kaiser et al., 2015). The role of $G_{i}$ signaling in breast cancer metastasis was also probed using inhibitory DREADDs (Yagi et al., 2011). Thus, while DREADDs serve predominantly as a nervous system-oriented tool, the utility of DREADDs certainly transcends the nervous system.

\section{Energy balance and DREADDs}

The field of energy balance stands apart as highly unique and integral to the development and use of DREADD technology. Homeostatic energy balance entails a complicated interplay of mechanisms promoting energy consumption, via feeding and 
energy expenditure, through regulatory mechanisms of metabolic rate, including oxygen consumption, thermogenesis, and physical activity. A wealth of literature has been devoted to the parsing and manipulation of anatomical areas, cell types, and circuits underlying feeding behaviors, including an animal's sensitivity to satiety states, its drive to forage and seek out food, and its instinct to ingest food of caloric or hedonic value while avoiding the consumption of contaminated or non-nutritional food. Much of this literature has focused on the hypothalamus, a highly complicated region of the mammalian brain with hundreds of distinct nuclei and remarkable heterogeneity. Classical lesion and electrical stimulation studies have identified regions of the hypothalamus that are both required and sufficient for distinct arms of energy homeostasis (Gold et al., 1977). However, such manipulations fail to control for fibers of passage and often affect areas outside the intended area of study. Furthermore, these methodologies are often obscured by the different functions of countless molecularly defined populations of cells in each of these hypothalamic nuclei.

The advent of remote, reversible tools like DREADDs has greatly facilitated the functional dissection of neural subpopulations and circuits underlying energy balance, revealing discrete, defined as well as parallel, redundant pathways regulating these critical responses. The first of these studies examined the role of agouti-related peptide (AgRP)-expressing neurons of the arcuate nucleus (ARC) at the base of the hypothalamus. Previous evidence, deduced via brain-slice electrophysiology, demonstrated state-dependent neural activity of this population, whereby $\mathrm{ARC}^{\mathrm{AgRP}}$ cells were relatively quiescent if the animals were killed in the sated condition, but displayed a fourfold increase in basal action potential frequency when killed in the fasted condition (Takahashi and Cone, 2005). Indeed upregulation of Agrp transcripts expressed in these neurons also is contingent on the appetitestate of the animal (Korner et al., 2000). Therefore, one would predict that acute manipulation of these cells would bidirectionally control feeding behavior. Indeed, chemogenetic activation of $\mathrm{ARC}^{\mathrm{AgRP}}$ neurons rapidly promoted voracious food intake, even in calorically replete mice during periods of the day when rodents are relatively inactive (Krashes et al., 2011; Steculorum et al., 2016).

Using combinatorial knock-out mouse lines, the early feeding phase following DREADD-mediated ARC ${ }^{\mathrm{AgRP}}$ activation was attributed to the role of the fast-acting neurotransmitter GABA and/or NPY, while AgRP was capable of promoting food intake over an extended period of time (Krashes et al., 2013), supporting previous pharmacology studies (Clark et al., 1984; Rossi et al., 1998; Semjonous et al., 2009). However, it should be noted that these experiments were performed in genetic knock-out models that cannot account for compensatory mechanisms that likely play a role in shaping homeostatic feeding circuits (Luquet et al., 2005). Notably, $\mathrm{G}_{\mathrm{s}}$-coupled DREADD-mediated ARC ${ }^{\mathrm{AgRP}}$ neuron activation orchestrated sustained elevated food consumption from hours to days analogous to that seen following pharmacological injection of AgRP (Nakajima et al., 2016). Recently, the vital role of GABA in dictating feeding behavior was demonstrated exercising a novel knockout strategy whereby the genes encoding glutamic acid decarboxylase $(G A D)$, the enzymes responsible for the synthesis of GABA, were selectively deleted in $\mathrm{ARC}^{\mathrm{AgRP}}$ neurons leading to lethal body weight loss (Meng et al., 2016).

Notably, in the absence of food, CNO-mediated activation of $\mathrm{ARC}^{\mathrm{AgRP}}$ neurons led to a potent increase in home-cage locomotor activity, a proxy of foraging behavior. Remarkably, this hyperactivity was completely abrogated when food was accessible, suggesting for the first time that ARC ${ }^{\mathrm{AgRP}}$ neurons may encode the appetitive or food-seeking phase of energy intake (Krashes et al., 2011). Strengthening this hypothesis, $\mathrm{CNO}$-mediated $\mathrm{ARC}^{\mathrm{AgRP}}$ activation, similar to physiological hunger, drastically augmented an animal's willingness to work for food in an instrumental nose-poke task, often used as a measure or motivational drive (Krashes et al., 2011). Finally, remote $\mathrm{ARC}^{\mathrm{AgRP}}$ stimulation following $\mathrm{CNO}$ administrations drastically attenuated oxygen consumption and shifted respiratory exchange ratio up, which is indicative of carbohydrates being the predominant fuel source, likely through inhibition of brown adipose tissue (BAT)-mediated thermogenesis (Krashes et al., 2011).

To identify the major source of excitatory input to ARC ${ }^{\text {AgRP }}$ neurons, which is decisive in preserving optimal body weight (Liu et al., 2012), a dual approach using rabies retrograde tracing and channelrhodopsin2-assisted circuit mapping identified a subpopulation of glutamatergic neurons in the PVH marked by the expression of thyrotropin-releasing hormone (TRH; Krashes et al., 2014). After establishing functional connectivity between $\mathrm{PVH}^{\mathrm{TRH}} \rightarrow \mathrm{ARC}^{\mathrm{AgRP}}$ neurons, the relative contribution of $\mathrm{PVH}^{\mathrm{TRH}}$ neurons on feeding behavior was directly assessed. Chemogenetic stimulation of $\mathrm{PVH}^{\mathrm{TRH}}$ cells enhanced food consumption in sated animals through an $\mathrm{ARC}^{\mathrm{AgRP}}$-mediated mechanism, as simultaneous silencing of $\mathrm{ARC}^{\mathrm{AgRP}}$ neurons abrogated this response (Krashes et al., 2014). Concordantly, $\mathrm{PVH}^{\mathrm{TRH}}$ activation resulted in a significant induction of Fos activity in $\mathrm{ARC}^{\mathrm{AgRP}}$ neurons. Supporting the notion that endogenous activity of the $\mathrm{PVH}^{\mathrm{TRH}} \rightarrow \mathrm{ARC}^{\mathrm{AgRP}}$ pathway is physiologically relevant for feeding, chemogenetic silencing of $\mathrm{PVH}^{\mathrm{TRH}}$ neurons drastically reduced food intake in hungry animals (Krashes et al., 2014).

Interestingly, ablation of ARC ${ }^{\mathrm{AgRP}}$ neurons in adulthood results in cessation of feeding behavior and ultimately starvation, demonstrating not only their importance but also actual requirement for survival (Gropp et al., 2005; Luquet et al., 2005). Reinforcing the necessity of these neurons in regulating feeding and maintaining homeostatic balance, acute silencing of this cell type significantly reduced food consumption in calorically depleted, hungry mice (Krashes et al., 2011). As proof of principle, CNO application to brain slices expressing either stimulatory or inhibitory DREADDs in ARC ${ }^{\mathrm{AgRP}}$ neurons transiently depolarized and induced burst firing or hyperpolarized and suppressed activity, respectively, demonstrating the efficacy of these tools. Moreover, Fos analyses validated biased CNO-mediated activation of neural activity in the ventral-medial portion of the ARC, where ARC $^{\text {AgRP }}$ neurons are located (Krashes et al., 2011).

Intermingled with anabolic $\mathrm{ARC}^{\mathrm{AgRP}}$ neurons are catabolic cells expressing pro-opiomelanocortin (POMC). This subpopulation is critical for sustaining apposite levels of energy balance as shown via genetic knock-out, ablation, and pharmacology approaches (Fan et al., 1997; Hahn et al., 1998; Yaswen et al., 1999; Gropp et al., 2005; Xu et al., 2005; Greenman et al., 2013; Zhan et al., 2013). To explore the acute role of ARC ${ }^{\text {POMC }}$ neurons in vivo, excitatory and inhibitory DREADDs were used to alter activity in an acute fashion and body weight and food intake were monitored over hours to days. Importantly, ex vivo electrophysiology established CNO-mediated changes in ARC ${ }^{\mathrm{POMC}}$ activity in a bidirectional manner, depending on the type of DREADD used (Atasoy et al., 2012; Zhan et al., 2013). Supporting the notion that the prolonged kinetics of a-melanocyte-stimulating hormone (aMSH), a major peptide cleaved from the pomc gene, affects 
energy balance, CNO-mediated activation of ARCPOMC neurons significantly lowered food intake over several hours (Steculorum et al., 2016) and externding this treatment lowered food intake and body weight over several days (Zhan et al., 2013), while chronic silencing this population markedly escalated food consumption over 24 hours (Atasoy et al., 2012). Interestingly and somewhat paradoxically, DREADD-mediated activation or inhibition of $\mathrm{ARC}^{\mathrm{POMC}}$ neurons promotes or diminishes endocannabinoid-induced feeding through cannabinoid receptors (CB1Rs; Koch et al., 2015).

A major downstream target of both $\mathrm{ARC}^{\mathrm{AgRP}}$ and $\mathrm{ARC}^{\mathrm{POMC}}$ neurons is the PVH (Broberger et al., 1998), an essential energy balance nucleus of the brain. Lesions of this site produce massive obesity affecting both arms of energy homeostasis (Gold et al., 1977). To investigate the acute role of this nucleus, a transcription factor required for the normal development of the $\mathrm{PVH}$, single-minded homolog 1 (Sim1), was used to target and bidirectionally manipulate activity of this anatomical locus. Chemogenetic activation of $\mathrm{PVH}^{\mathrm{SIM} 1}$ neurons, which marks the majority of this nucleus, or a subpopulation of $\mathrm{PVH}^{\mathrm{SIM} 1}$ cells labeled by nitric oxide synthase-1 $\left(\mathrm{PVH}^{\mathrm{Nos}}\right)$, dramatically reduced food intake in hungry mice and increased energy expenditure and subcutaneous intrascapular temperature (Sutton et al., 2014). Silencing $\mathrm{PVH}^{\text {SIM1 }}$ neurons evoked avid food consumption in replete mice with both ad libitum access to food as well as during an instrumental lever press assay where animals were trained to work for food reward (Atasoy et al., 2012). To parse out the downstream circuitry underlying this feeding phenotype, an axon-specific DREADD variant was engineered using neurexin to direct expression to terminals (Stachniak et al., 2014). After demonstrating the ability of this tool to reduce synaptic release probability and synaptic current amplitude, locally infused CNO was targeted at distinct downstream projection areas of $\mathrm{PVH}^{\mathrm{SIM} 1}$ neurons, of which the ventral lateral periaqueductal gray/DR (vlPAG/DR) field was identified as sufficient to evoke feeding comparable to soma activation (Stachniak et al., 2014).

To dissect which particular cell types in the PVH were mediating these acute effects on food intake, a number of mouse lines were generated granting access to acute chemogenetic manipulations. Melanocortin-4 receptors (Mc4Rs) are a major target of the agonist $\alpha$-MSH and antagonist/inverse agonist AgRP peptides released by $\mathrm{ARC}^{\mathrm{POMC}}$ and $\mathrm{ARC}{ }^{\mathrm{AgRP}}$ neurons, respectively (Ollmann et al., 1997; Hagan et al., 2000; Nijenhuis et al., 2001; Liu et al., 2012), making $\mathrm{PVH}^{\mathrm{Mc} 4 \mathrm{R}}$ a logical downstream substrate of these ARC-emanating populations. Indeed, $\mathrm{ARC}^{\mathrm{AgRP}}$ neurons were found to be functionally connected to $\mathrm{PVH}^{\mathrm{Mc} 4 \mathrm{R}}$ neurons through inhibitory mechanisms, anatomically placing them in an ideal position to integrate appetite status and signal satiety (Garfield et al., 2015). Accordingly, chemogenetic activation of $\mathrm{PVH}^{\mathrm{Mc} 4 \mathrm{R}}$ neurons, but not those expressing oxytocin $\left(\mathrm{PVH}^{\mathrm{Oxt}}\right)$, reduced food intake in physiologically hungry mice, even following an overnight fast (Sutton et al., 2014; Garfield et al., 2015). DREADD-mediated silencing of PVH ${ }^{\mathrm{Mc} 4 \mathrm{R}}$ neurons, but not discrete subsets labeled by corticotropin-releasing hormone $\left(\mathrm{PVH}^{\mathrm{CRH}}\right)$ or $\mathrm{PVH}^{\mathrm{Oxt}}$, enhanced food consumption in replete animals (Garfield et al., 2015). Moreover, in an instrumental nose-poke task, chemogenetic inhibition of $\mathrm{PVH}^{\mathrm{MC} 4 \mathrm{R}}$ neurons in sated mice significantly increased the motivation to attain a food reward, as measured by the highest number of consecutive nose pokes an animal performed to procure a single food pellet (Garfield et al., 2015). Of note, chemogenetic activation of PVH cells denoted by arginine vasopressin $\left(\mathrm{PVH}^{\mathrm{AVP}}\right)$ acutely constrained food intake during physiolog- ical hunger while chemogenetic inhibition partially reversed the anorexia-induced effects of the melanocortin agonist melanotan-II (Pei et al., 2014).

Chemogenetic tools have been applied to a number of other hypothalamic subsets of neurons regulating distinct phases of physiology. For example, cells located in the dorsomedial hypothalamus/dorsal hypothalamic area expressing leptin receptors (DMH/DHA ${ }^{\mathrm{LepR}}$ ) have been convincingly shown to promote BAT thermogenesis and locomotor activity that robustly induced changes in energy expenditure ultimately decreasing body weight (Rezai-Zadeh et al., 2014). Interestingly, chemogenetic inhibition of $\mathrm{DMH}^{\mathrm{LepR}}$ activity caused a rapid reduction of blood pressure in a diet-induced obesity mouse model, independent of changes in weight, similar to that observed by blocking leptin action with a specific antibody or antagonist (Magnus et al., 2011; Simonds et al., 2014). Selective chemogenetic stimulation of ARC neurons marked by the expression of the rat insulin promoter $\left(A R C^{R I P}\right)$ rapidly increased oxygen consumption and interscapular BAT temperature, effects absent when GABA release was perturbed (Kong et al., 2012). DREADD-mediated activation of lateral hypothalamic (LH) cells marked by vesicular GABA transporter (vGAT) potently drove consummatory behavior toward a palatable caloric liquid reward, chow, water, sucrose, saccharin, and even stimuli lacking biological relevance, such as a wooden block or the receptacles used to deliver reward (Jennings et al., 2015; Navarro et al., 2016), while acute silencing of LH ${ }^{\mathrm{VGAT}}$ neurons blunted these consummatory behaviors (Navarro et al., 2016). Furthermore, chemogenetic inactivation of steroidogenic factor 1 (SF1)-expressing neurons of the VMH both normalized glycemic control in mice with selective $\mathrm{VMH}^{\mathrm{SF} 1}$ deletion of uncoupling protein 2 (Toda et al., 2016) and diminished the counterregulatory response that promotes endogenous glucose production within the context of 2-deoxyglucose-glucoprivation induction (Garfield et al., 2014). Acute stimulation of upstream neurons labeled by the expression of cholecystokinin (CCK) or LepR located in the lateral parabrachial nucleus (LPBN) prompted increased glucose concentration as well as elevated serum levels of the counterregulatory-response hormones glucagon and corticosterone (Flak et al., 2014; Garfield et al., 2014). Conversely, while silencing of LPBN ${ }^{\text {CCK }}$ or LPBN ${ }^{\mathrm{LepR}}$ neurons had no effect on blood glucose concentration in normoglycemic (ad libitum fed) mice, this same manipulation before the induction of acute glucoprivation severely reduced the counterregulatory response (Flak et al., 2014; Garfield et al., 2014).

A number of brain regions and molecularly defined cell types in other extrahypothalamic nuclei involved in energy balance have been assessed using chemogenetic tactics. For instance, a subpopulation of GABAergic neurons marked by protein kinase $\mathrm{C}-\delta(\mathrm{PKC}-\delta)$ in the lateral subdivision of the amygdala central nucleus $\left(\mathrm{CEI}{ }^{\mathrm{PKC}-\delta}\right)$ respond to anorexigenic agents that strongly inhibit feeding in food-deprived mice, such as CCK, lithium chloride ( $\mathrm{LiCl}$ ), and lipopolysaccharide (LPS). CNO-mediated acute silencing of $\mathrm{CEI}{ }^{\mathrm{PKC}-\delta}$ neurons substantially reduced the hypophagic effect of some of these anorectic vehicles, overcame the suppression of feeding by the bitter tastant quinine, and statistically augmented food consumption in sated mice (Cai et al., 2014).

Another population of appetite-suppressing neurons whose activity is triggered by anorectic hormones, such as amylin and CCK, in addition to LiCl and LPS, compounds that mimic the effects of toxicity and sickness, respectively, were identified in the LPBN via the expression of calcitonin gene-related peptide 
(CGRP). Acute activation of this subpopulation curtailed food intake both during baseline conditions and following a $24 \mathrm{~h}$ fast, while chronic stimulation caused a prominent diminution in body weight due to hypophagia (Carter et al., 2013). Chemogenetic inhibition of LPBN ${ }^{\text {CGRP }}$ neurons blunted the suppression of appetite observed after injection of the above anorexigenic agents. This acute silencing approach also attenuated LiClmediated conditioned place aversion (Carter et al., 2015). To assess the relevant circuitry mediating these effects, the authors used a two-virus system taking advantage of the exclusive retrograde capability of CAV2 (Soudais et al., 2001). After determining that a major target of LPBN ${ }^{\text {CGRP }}$ neurons was the CEI, mice were coinjected with a CAV2-Cre virus in this downstream CEI site, which traveled in the retrograde direction back to the LPBN where a Cre-dependent virus expressing inhibitory DREADDs was targeted, selectively marking LPBN neurons that project to the CEI. CNO-mediated silencing of this pathway partially reversed the loss of appetite due to LiCl or LPS injection (Carter et al., 2013).

The nucleus of the solitary tract (NTS) is considered the primary node in which meal-related and metabolic signals from the periphery are integrated with neural networks of the brain (Grill and Hayes, 2012). Supporting this notion, chemogenetic activation of NTS neurons expressing CCK (NTS ${ }^{\mathrm{CCK}}$ ) selectively perturbed both $24 \mathrm{~h}$ ad libitum food intake and postfast refeeding, while failing to influence glucose homeostasis, an effect that was dependent on functional CCK-A receptors (D'Agostino et al., 2016). Chronic NTS ${ }^{\text {CCK }}$ neural activation achieved through repeated dosing of $\mathrm{CNO}$ resulted in a pronounced reduction in body weight because of hypophagia (D'Agostino et al., 2016). Chemogenetic activation of another subgroup of NTS neurons, highlighted by the expression of the appetite suppressant glucagon-like peptide (GLP-1), was shown to curb high-fat food intake, and this effect could be recapitulated by selectively stimulating NTS ${ }^{\text {GLP-1 }}$ activity at terminals in the VTA following focal infusion of CNO to this brain site (Wang et al., 2015). Given the incredible complexity of neural circuitry in hypothalamic and extrahypothalamic nuclei regulating feeding behavior, DREADDs have massively advanced our understanding of the neural underpinnings of various components of energy balance.

\section{Conclusion}

DREADDs continue to improve upon previous iterations through modifications to both the lock (receptor) and key (chemical actuator) components. As a direct result of this persistent development, use of these tools will continue to rise. Importantly, other methods of neural manipulation, such as optogenetics (Deisseroth, 2015) or techniques requiring the use of radio waves or magnetic fields (Stanley et al., 2016; Wheeler et al., 2016), have been similarly used to demonstrate sufficiency and necessity of neural subpopulations and circuits underlying a myriad of behaviors. Use of multiplexing these discrete methodologies will only expand the possibilities in dissecting key physiological systems regulating behavioral output across species, an overarching goal of modern neuroscience.

\section{References}

Alexander GM, Rogan SC, Abbas AI, Armbruster BN, Pei Y, Allen JA, Nonneman RJ, Hartmann J, Moy SS, Nicolelis MA, McNamara JO, Roth BL (2009) Remote control of neuronal activity in transgenic mice expressing evolved G protein-coupled receptors. Neuron 63:27-39. CrossRef Medline

Anderson SA, Michaelides M, Zarnegar P, Ren Y, Fagergren P, Thanos PK, Wang GJ,
Bannon M, Neumaier JF, Keller E, Volkow ND, Hurd YL (2013) Impaired periamygdaloid-cortex prodynorphin is characteristic of opiate addiction and depression. J Clin Invest 123:5334-5341. CrossRef Medline

Arenkiel BR, Klein ME, Davison IG, Katz LC, Ehlers MD (2008) Genetic control of neuronal activity in mice conditionally expressing TRPV1. Nat Methods 5:299-302. CrossRef Medline

Armbruster BN, Roth BL (2005) Mining the receptorome. J Biol Chem 280: 5129-5132. CrossRef Medline

Armbruster BN, Li X, Pausch MH, Herlitze S, Roth BL (2007) Evolving the lock to fit the key to create a family of $G$ protein-coupled receptors potently activated by an inert ligand. Proc Natl Acad Sci U S A 104: 5163-5168. CrossRef Medline

Aston-Jones G, RajkowskiJ, Cohen J (1999) Role of locus coeruleus in attention and behavioral flexibility. Biol Psychiatry 46:1309-1320. CrossRef Medline

Atasoy D, Aponte Y, Su HH, Sternson SM (2008) A FLEX switch targets Channelrhodopsin-2 to multiple cell types for imaging and long-range circuit mapping. J Neurosci 28:7025-7030. CrossRef Medline

Atasoy D, Betley JN, Su HH, Sternson SM (2012) Deconstruction of a neural circuit for hunger. Nature 488:172-177. CrossRef Medline

Autry AE, Adachi M, Nosyreva E, Na ES, Los MF, Cheng PF, Kavalali ET, Monteggia LM (2011) NMDA receptor blockade at rest triggers rapid behavioural antidepressant responses. Nature 475:91-95. CrossRef Medline

Bender D, Holschbach M, Stöcklin G (1994) Synthesis of n.c.a. carbon-11 labelled clozapine and its major metabolite clozapine- $\mathrm{N}$-oxide and comparison of their biodistribution in mice. Nucl Med Biol 21:921-925. CrossRef Medline

Berman RM, Cappiello A, Anand A, Oren DA, Heninger GR, Charney DS, Krystal JH (2000) Antidepressant effects of ketamine in depressed patients. Biol Psychiatry 47:351-354. CrossRef Medline

Bishop AC, Shah K, Liu Y, Witucki L, Kung C, Shokat KM (1998) Design of allele-specific inhibitors to probe protein kinase signaling. Curr Biol 8:257-266. CrossRef Medline

Bishop A, Buzko O, Heyeck-Dumas S, Jung I, Kraybill B, Liu Y, Shah K, Ulrich S, Witucki L, Yang F, Zhang C, Shokat KM (2000) Unnatural ligands for engineered proteins: new tools for chemical genetics. Annu Rev Biophysics Biomol Struct 29:577-606. CrossRef Medline

Bock R, Shin JH, Kaplan AR, Dobi A, Markey E, Kramer PF, Gremel CM, Christensen CH, Adrover MF, Alvarez VA (2013) Strengthening the accumbal indirect pathway promotes resilience to compulsive cocaine use. Nat Neurosci 16:632-638. CrossRef Medline

Brancaccio M, Maywood ES, Chesham JE, Loudon AS, Hastings MH (2013) A Gq-Ca2 + axis controls circuit-level encoding of circadian time in the suprachiasmatic nucleus. Neuron 78:714-728. CrossRef Medline

Broberger C, Johansen J, Johansson C, Schalling M, Hökfelt T (1998) The neuropeptide $\mathrm{Y} /$ agouti gene-related protein (AGRP) brain circuitry in normal, anorectic, and monosodium glutamate-treated mice. Proc Natl Acad Sci U S A 95:15043-15048. CrossRef Medline

Brust RD, Corcoran AE, Richerson GB, Nattie E, Dymecki SM (2014) Functional and developmental identification of a molecular subtype of brain serotonergic neuron specialized to regulate breathing dynamics. Cell Rep 9:2152-2165. CrossRef Medline

Bull C, Freitas KC, Zou S, Poland RS, Syed WA, Urban DJ, Minter SC, Shelton KL, Hauser KF, Negus SS, Knapp PE, Bowers MS (2014) Rat nucleus accumbens core astrocytes modulate reward and the motivation to self-administer ethanol after abstinence. Neuropsychopharmacology 39:2835-2845. CrossRef Medline

Cai H, Haubensak W, Anthony TE, Anderson DJ (2014) Central amygdala PKC-delta $(+)$ neurons mediate the influence of multiple anorexigenic signals. Nat Neurosci 17:1240-1248. CrossRef Medline

Carreno FR, Donegan JJ, Boley AM, Shah A, DeGuzman M, Frazer A, Lodge DJ (2015) Activation of a ventral hippocampus-medial prefrontal cortex pathway is both necessary and sufficient for an antidepressant response to ketamine. Mol Psychiatry. Advance online publication. Retrieved July 20, 2016. CrossRef Medline

Carter ME, Soden ME, Zweifel LS, Palmiter RD (2013) Genetic identification of a neural circuit that suppresses appetite. Nature 503:111-114. CrossRef Medline

Carter ME, Han S, Palmiter RD (2015) Parabrachial calcitonin gene-related peptide neurons mediate conditioned taste aversion. J Neurosci 35: 4582-4586. CrossRef Medline

Carvalho Poyraz F, Holzner E, Bailey MR, Meszaros J, Kenney L, Kheirbek MA, Balsam PD, Kellendonk C (2016) Decreasing striatopallidal path- 
way function enhances motivation by energizing the initiation of goaldirected Action. J Neurosci 36:5988-6001. CrossRef Medline

Cassataro D, Bergfeldt D, Malekian C, Van Snellenberg JX, Thanos PK, Fishell G, Sjulson L (2014) Reverse pharmacogenetic modulation of the nucleus accumbens reduces ethanol consumption in a limited access paradigm. Neuropsychopharmacology 39:283-290. CrossRef Medline

Chang SE, Todd TP, Bucci DJ, Smith KS (2015) Chemogenetic manipulation of ventral pallidal neurons impairs acquisition of sign-tracking in rats. Eur J Neurosci 42:3105-3116. CrossRef Medline

Chen X, Ye H, Kuruvilla R, Ramanan N, Scangos KW, Zhang C, Johnson NM, England PM, Shokat KM, Ginty DD (2005) A chemical-genetic approach to studying neurotrophin signaling. Neuron 46:13-21. CrossRef Medline

Chen X, Choo H, Huang XP, Yang X, Stone O, Roth BL, Jin J (2015) The first structure-activity relationship studies for designer receptors exclusively activated by designer drugs. ACS Chem Neurosci 6:476-484. CrossRef Medline

Clark JT, Kalra PS, Crowley WR, Kalra SP (1984) Neuropeptide Y and human pancreatic polypeptide stimulate feeding behavior in rats. Endocrinology 115:427-429. CrossRef Medline

Cohen MS, Zhang C, Shokat KM, Taunton J (2005) Structural bioinformatics-based design of selective, irreversible kinase inhibitors. Science 308:1318-1321. CrossRef Medline

Collot V, Sopkova-de Oliveira Santos J, Schumann-Bard P, Colloc'h N, Mackenzie ET, Rault S (2003) Synthesis, pharmacological study and modeling of 7-methoxyindazole and related substituted indazoles as neuronal nitric oxide synthase inhibitors. J Enzyme Inhib Med Chem 18: 195-199. CrossRef Medline

D’Agostino G, Lyons DJ, Cristiano C, Burke LK, Madara JC, Campbell JN, Garcia AP, Land BB, Lowell BB, Dileone RJ, Heisler LK (2016) Appetite controlled by a cholecystokinin nucleus of the solitary tract to hypothalamus neurocircuit. eLife Sciences 5:pii:e12225. CrossRef Medline

Dar AC, Das TK, Shokat KM, Cagan RL (2012) Chemical genetic discovery of targets and anti-targets for cancer polypharmacology. Nature 486: 80-84. CrossRef Medline

Deisseroth K (2015) Optogenetics: 10 years of microbial opsins in neuroscience. Nat Neurosci 18:1213-1225. CrossRef Medline

den Hartog C, Zamudio-Bulcock P, Nimitvilai S, Gilstrap M, Eaton B, Fedarovich H, Motts A, Woodward JJ (2016) Inactivation of the lateral orbitofrontal cortex increases drinking in ethanol-dependent but not non-dependent mice. Neuropharmacology 107:451-459. CrossRef Medline

Eldridge MA, Lerchner W, Saunders RC, Kaneko H, Krausz KW, Gonzalez FJ, Ji B, Higuchi M, Minamimoto T, Richmond BJ (2016) Chemogenetic disconnection of monkey orbitofrontal and rhinal cortex reversibly disrupts reward value. Nat Neurosci 19:37-39. CrossRef Medline

Fan W, Boston BA, Kesterson RA, Hruby VJ, Cone RD (1997) Role of melanocortinergic neurons in feeding and the agouti obesity syndrome. Nature 385:165-168. CrossRef Medline

Farrell MS, Pei Y, Wan Y, Yadav PN, Daigle TL, Urban DJ, Lee HM, Sciaky N, Simmons A, Nonneman RJ, Huang XP, Hufeisen SJ, Guettier JM, Moy SS, Wess J, Caron MG, Calakos N, Roth BL (2013) A Galphas DREADD mouse for selective modulation of cAMP production in striatopallidal neurons. Neuropsychopharmacology 38:854-862. CrossRef Medline

Ferguson SM, Eskenazi D, Ishikawa M, Wanat MJ, Phillips PE, Dong Y, Roth BL, Neumaier JF (2011) Transient neuronal inhibition reveals opposing roles of indirect and direct pathways in sensitization. Nat Neurosci 14: 22-24. CrossRef Medline

Ferguson SM, Phillips PE, Roth BL, Wess J, Neumaier JF (2013) Directpathway striatal neurons regulate the retention of decision-making strategies. J Neurosci 33:11668-11676. CrossRef Medline

Flak JN, Myers B, Solomon MB, McKlveen JM, Krause EG, Herman JP (2014) Role of paraventricular nucleus-projecting norepinephrine/ epinephrine neurons in acute and chronic stress. Eur J Neurosci 39: 1903-1911. CrossRef Medline

Fortress AM, Hamlett ED, Vazey EM, Aston-Jones G, Cass WA, Boger HA, Granholm AC (2015) Designer receptors enhance memory in a mouse model of Down syndrome. J Neurosci 35:1343-1353. CrossRef Medline

Garfield AS, Shah BP, Madara JC, Burke LK, Patterson CM, Flak J, Neve RL, Evans ML, Lowell BB, Myers MG Jr, Heisler LK (2014) A parabrachialhypothalamic cholecystokinin neurocircuit controls counterregulatory responses to hypoglycemia. Cell Metab 20:1030-1037. CrossRef Medline Garfield AS, Li C, Madara JC, Shah BP, Webber E, Steger JS, Campbell JN,
Gavrilova O, Lee CE, Olson DP, Elmquist JK, Tannous BA, Krashes MJ, Lowell BB (2015) A neural basis for melanocortin-4 receptor-regulated appetite. Nat Neurosci 18:863-871. CrossRef Medline

Garner AR, Rowland DC, Hwang SY, Baumgaertel K, Roth BL, Kentros C, Mayford M (2012) Generation of a synthetic memory trace. Science 335: 1513-1516. CrossRef Medline

Gold RM, Ieni JR, Simson EL (1977) Delayed or precocious hyperphagia after symmetrical or asymmetrical hypothalamic knife cuts in male and female weanling rats. Physiol Behav 18:275-281. CrossRef Medline

Goto A, Nakahara I, Yamaguchi T, Kamioka Y, Sumiyama K, Matsuda M, Nakanishi S, Funabiki K (2015) Circuit-dependent striatal PKA and ERK signaling underlies rapid behavioral shift in mating reaction of male mice. Proc Natl Acad Sci U S A 112:6718-6723. CrossRef Medline

Greenman Y, Kuperman Y, Drori Y, Asa SL, Navon I, Forkosh O, Gil S, Stern $\mathrm{N}$, Chen A (2013) Postnatal ablation of POMC neurons induces an obese phenotype characterized by decreased food intake and enhanced anxiety-like behavior. Mol Endocrinol 27:1091-1102. CrossRef Medline

Grill HJ, Hayes MR (2012) Hindbrain neurons as an essential hub in the neuroanatomically distributed control of energy balance. Cell Metab 16: 296-309. CrossRef Medline

Gropp E, Shanabrough M, Borok E, Xu AW, Janoschek R, Buch T, Plum L, Balthasar N, Hampel B, Waisman A, Barsh GS, Horvath TL, Brüning JC (2005) Agouti-related peptide-expressing neurons are mandatory for feeding. Nat Neurosci 8:1289-1291. CrossRef Medline

Guettier JM, Gautam D, Scarselli M, Ruiz de Azua I, Li JH, Rosemond E, Ma X, Gonzalez FJ, Armbruster BN, Lu H, Roth BL, Wess J (2009) A chemical-genetic approach to study $\mathrm{G}$ protein regulation of beta cell function in vivo. Proc Natl Acad Sci U S A 106:19197-19202. CrossRef Medline

Güler AD, Rainwater A, Parker JG, Jones GL, Argilli E, Arenkiel BR, Ehlers MD, Bonci A, Zweifel LS, Palmiter RD (2012) Transient activation of specific neurons in mice by selective expression of the capsaicin receptor. Nat Commun 3:746. CrossRef Medline

Hagan MM, Rushing PA, Pritchard LM, Schwartz MW, Strack AM, Van Der Ploeg LH, Woods SC, Seeley RJ (2000) Long-term orexigenic effects of AgRP-(83132) involve mechanisms other than melanocortin receptor blockade. Am J Physiol Regul Integr Comp Physiol 279:R47-R52. Medline

Hahn TM, Breininger JF, Baskin DG, Schwartz MW (1998) Coexpression of Agrp and NPY in fasting-activated hypothalamic neurons. Nat Neurosci 1:271-272. CrossRef Medline

Häring D, Distefano MD (2001) Enzymes by design: chemogenetic assembly of transamination active sites containing lysine residues for covalent catalysis. Bioconjug Chem 12:385-390. CrossRef Medline

Hwang DY, Carlezon WA Jr, Isacson O, Kim KS (2001) A high-efficiency synthetic promoter that drives transgene expression selectively in noradrenergic neurons. Hum Gene Ther 12:1731-1740. CrossRef Medline

Ishii K, Kubo K, Endo T, Yoshida K, Benner S, Ito Y, Aizawa H, Aramaki M, Yamanaka A, Tanaka K, Takata N, Tanaka KF, Mimura M, Tohyama C, Kakeyama M, Nakajima K (2015) Neuronal heterotopias affect the activities of distant brain areas and lead to behavioral deficits. J Neurosci 35:12432-12445. CrossRef Medline

Jain S, Ruiz de Azua I, Lu H, White MF, Guettier JM, Wess J (2013) Chronic activation of a designer $\mathrm{G}(\mathrm{q})$-coupled receptor improves beta cell function. J Clin Invest 123:1750-1762. CrossRef Medline

Jann MW, Lam YW, Chang WH (1994) Rapid formation of clozapine in guinea-pigs and man following clozapine-N-oxide administration. Arch Int Pharmacodyn Ther 328:243-250. Medline

Jennings JH, Ung RL, Resendez SL, Stamatakis AM, Taylor JG, Huang J, Veleta K, Kantak PA, Aita M, Shilling-Scrivo K, Ramakrishnan C, Deisseroth K, Otte S, Stuber GD (2015) Visualizing hypothalamic network dynamics for appetitive and consummatory behaviors. Cell 160:516-527. CrossRef Medline

Kaiser E, Schröder L, Wiesen K, Wess J, Tian Q, Kaestner L, Lipp P (2015) Novel roles of Gq-dependent signal transduction for cardiac pacemaking and cardiac impulse propagation studied by Gq-KO and a DREADD. Biophysical J 108:131a-132a. CrossRef

Klein G, Humbert N, Gradinaru J, Ivanova A, Gilardoni F, Rusbandi UE, Ward TR (2005) Tailoring the active site of chemzymes by using a chemogenetic-optimization procedure: towards substrate-specific artificial hydrogenases based on the biotin-avidin technology. Angewandte Chemie 44:7764-7767. CrossRef Medline

Koch M, Varela L, Kim JG, Kim JD, Hernández-NuñoF, Simonds SE, Cas- 
torena CM, Vianna CR, Elmquist JK, Morozov YM, Rakic P, Bechmann I, Cowley MA, Szigeti-Buck K, Dietrich MO, Gao XB, Diano S, Horvath TL (2015) Hypothalamic POMC neurons promote cannabinoid-induced feeding. Nature 519:45-50. CrossRef Medline

Koike H, Demars MP, Short JA, Nabel EM, Akbarian S, Baxter MG, Morishita H (2016) Chemogenetic inactivation of dorsal anterior cingulate cortex neurons disrupts attentional behavior in mouse. Neuropsychopharmacology 41:1014-1023. CrossRef Medline

Kong D, Tong Q, Ye C, Koda S, Fuller PM, Krashes MJ, Vong L, Ray RS, Olson DP, Lowell BB (2012) GABAergic RIP-Cre neurons in the arcuate nucleus selectively regulate energy expenditure. Cell 151:645-657. CrossRef Medline

Korner J, Wardlaw SL, Liu SM, Conwell IM, Leibel RL, Chua SC Jr (2000) Effects of leptin receptor mutation on Agrp gene expression in fed and fasted lean and obese (LA/N-faf) rats. Endocrinology 141:2465-2471. CrossRef Medline

Kozorovitskiy Y, Saunders A, Johnson CA, Lowell BB, Sabatini BL (2012) Recurrent network activity drives striatal synaptogenesis. Nature 485: 646-650. CrossRef Medline

Krashes MJ, Koda S, Ye C, Rogan SC, Adams AC, Cusher DS, Maratos-Flier E, Roth BL, Lowell BB (2011) Rapid, reversible activation of AgRP neurons drives feeding behavior in mice. J Clin Invest 121:1424-1428. CrossRef Medline

Krashes MJ, Shah BP, Koda S, Lowell BB (2013) Rapid versus delayed stimulation of feeding by the endogenously released AgRP neuron mediators GABA, NPY, and AgRP. Cell Metab 18:588-595. CrossRef Medline

Krashes MJ, Shah BP, Madara JC, Olson DP, Strochlic DE, Garfield AS, Vong L, Pei H, Watabe-Uchida M, Uchida N, Liberles SD, Lowell BB (2014) An excitatory paraventricular nucleus to AgRP neuron circuit that drives hunger. Nature 507:238-242. CrossRef Medline

Lerchner W, Xiao C, Nashmi R, Slimko EM, van Trigt L, Lester HA, Anderson DJ (2007) Reversible silencing of neuronal excitability in behaving mice by a genetically targeted, ivermectin-gated $\mathrm{Cl}-$ channel. Neuron 54: 35-49. CrossRef Medline

Li C, Rainnie DG (2014) Bidirectional regulation of synaptic plasticity in the basolateral amygdala induced by the D1-like family of dopamine receptors and group II metabotropic glutamate receptors. J Physiol 592: 4329-4351. CrossRef Medline

Li H, Penzo MA, Taniguchi H, Kopec CD, Huang ZJ, Li B (2013) Experience-dependent modification of a central amygdala fear circuit. Nat Neurosci 16:332-339. CrossRef Medline

Li JH, Jain S, McMillin SM, Cui Y, Gautam D, Sakamoto W, Lu H, Jou W, McGuinness OP, Gavrilova O, Wess J (2013) A novel experimental strategy to assess the metabolic effects of selective activation of a G(q)coupled receptor in hepatocytes in vivo. Endocrinology 154:3539-3551. CrossRef Medline

Liu T, Kong D, Shah BP, Ye C, Koda S, Saunders A, Ding JB, Yang Z, Sabatini BL, Lowell BB (2012) Fasting activation of AgRP neurons requires NMDA receptors and involves spinogenesis and increased excitatory tone. Neuron 73:511-522. CrossRef Medline

Liu Y, Shah K, Yang F, Witucki L, Shokat KM (1998) A molecular gate which controls unnatural ATP analogue recognition by the tyrosine kinase v-Src. Bioorg Med Chem 6:1219-1226. CrossRef Medline

López AJ, Kramár E, Matheos DP, White AO, Kwapis J, Vogel-Ciernia A, Sakata K, Espinoza M, Wood MA (2016) Promoter-specific effects of DREADD modulation on hippocampal synaptic plasticity and memory formation. J Neurosci 36:3588-3599. CrossRef Medline

Luquet S, Perez FA, Hnasko TS, Palmiter RD (2005) NPY/AgRP neurons are essential for feeding in adult mice but can be ablated in neonates. Science 310:683-685. CrossRef Medline

Macpherson T, Morita M, Hikida T (2014) Striatal direct and indirect pathways control decision-making behavior. Front Psychol 5:1301. CrossRef Medline

Magnus CJ, Lee PH, Atasoy D, Su HH, Looger LL, Sternson SM (2011) Chemical and genetic engineering of selective ion channel-ligand interactions. Science 333:1292-1296. CrossRef Medline

Mahler SV, Vazey EM, Beckley JT, Keistler CR, McGlinchey EM, Kaufling J, Wilson SP, Deisseroth K, Woodward JJ, Aston-Jones G (2014) Designer receptors show role for ventral pallidum input to ventral tegmental area in cocaine seeking. Nat Neurosci 17:577-585. CrossRef Medline

McClain JL, Fried DE, Gulbransen BD (2015) Agonist-evoked Ca signaling in enteric glia drives neural programs that regulate intestinal motility in mice. Cell Mol Gastroenterol Hepatol 1:631-645. CrossRef Medline

Meng F, Han Y, Srisai D, Belakhov V, Farias M, Xu Y, Palmiter RD, Baasov T, Wu Q (2016) New inducible genetic method reveals critical roles of GABA in the control of feeding and metabolism. Proc Natl Acad Sci U S A 113:3645-3650. CrossRef Medline

Mizoguchi H, Katahira K, Inutsuka A, Fukumoto K, Nakamura A, Wang T, Nagai T, Sato J, Sawada M, Ohira H, Yamanaka A, Yamada K (2015) Insular neural system controls decision-making in healthy and methamphetamine-treated rats. Proc Natl Acad Sci U S A 112:E3930-3939. CrossRef Medline

Mohawk JA, Takahashi JS (2011) Cell autonomy and synchrony of suprachiasmatic nucleus circadian oscillators. Trends Neurosci 34:349-358. CrossRef Medline

Nair SG, Strand NS, Neumaier JF (2013) DREADDing the lateral habenula: a review of methodological approaches for studying lateral habenula function. Brain Res 1511:93-101. CrossRef Medline

Nakajima K, Wess J (2012) Design and functional characterization of a novel, arrestin-biased designer G protein-coupled receptor. Mol Pharmacol 82:575-582. CrossRef Medline

Nakajima K, Cui Z, Li C, Meister J, Cui Y, Fu O, Smith AS, Jain S, Lowell BB, Krashes MJ, Wess J (2016) Gs-coupled GPCR signalling in AgRP neurons triggers sustained increase in food intake. Nat Commun 7:10268. CrossRef Medline

Navarro M, Olney JJ, Burnham NW, Mazzone CM, Lowery-Gionta EG, Pleil KE, Kash TL, Thiele TE (2016) Lateral hypothalamus GABAergic neurons modulate consummatory behaviors regardless of the caloric content or biological relevance of the consumed stimuli. Neuropsychopharmacology 41:1505-1512. CrossRef Medline

Nijenhuis WA, Oosterom J, Adan RA (2001) $\operatorname{AgRP}(83-132)$ acts as an inverse agonist on the human-melanocortin-4 receptor. Mol Endocrinol 15:164-171. CrossRef Medline

Ollmann MM, Wilson BD, Yang YK, Kerns JA, Chen Y, Gantz I, Barsh GS (1997) Antagonism of central melanocortin receptors in vitro and in vivo by agouti-related protein. Science 278:135-138. CrossRef Medline

Orr AG, Hsiao EC, Wang MM, Ho K, Kim DH, Wang X, Guo W, Kang J, Yu GQ, Adame A, Devidze N, Dubal DB, Masliah E, Conklin BR, Mucke L (2015) Astrocytic adenosine receptor A2A and Gs-coupled signaling regulate memory. Nat Neurosci 18:423-434. CrossRef Medline

Pei H, Sutton AK, Burnett KH, Fuller PM, Olson DP (2014) AVP neurons in the paraventricular nucleus of the hypothalamus regulate feeding. Mol Metab 3:209-215. CrossRef Medline

Peñagarikano O, Lázaro MT, Lu XH, Gordon A, Dong H, Lam HA, Peles E, Maidment NT, Murphy NP, Yang XW, Golshani P, Geschwind DH (2015) Exogenous and evoked oxytocin restores social behavior in the Cntnap2 mouse model of autism. Sci Transl Med 7:271ra8. CrossRef Medline

Perova Z, Delevich K, Li B (2015) Depression of excitatory synapses onto parvalbumin interneurons in the medial prefrontal cortex in susceptibility to stress. J Neurosci 35:3201-3206. CrossRef Medline

Pina MM, Young EA, Ryabinin AE, Cunningham CL (2015) The bed nucleus of the stria terminalis regulates ethanol-seeking behavior in mice. Neuropharmacology 99:627-638. CrossRef Medline

Pleil KE, Rinker JA, Lowery-Gionta EG, Mazzone CM, McCall NM, Kendra AM, Olson DP, Lowell BB, Grant KA, Thiele TE, Kash TL (2015) NPY signaling inhibits extended amygdala CRF neurons to suppress binge alcohol drinking. Nat Neurosci 18:545-552. CrossRef Medline

Ray RS, Corcoran AE, Brust RD, Kim JC, Richerson GB, Nattie E, Dymecki SM (2011) Impaired respiratory and body temperature control upon acute serotonergic neuron inhibition. Science 333:637-642. CrossRef Medline

Redfern CH, Coward P, Degtyarev MY, Lee EK, Kwa AT, Hennighausen L, Bujard H, Fishman GI, Conklin BR (1999) Conditional expression and signaling of a specifically designed Gi-coupled receptor in transgenic mice. Nat Biotechnol 17:165-169. CrossRef Medline

Redfern CH, Degtyarev MY, Kwa AT, Salomonis N, Cotte N, Nanevicz T, Fidelman N, Desai K, Vranizan K, Lee EK, Coward P, Shah N, Warrington JA, Fishman GI, Bernstein D, Baker AJ, Conklin BR (2000) Conditional expression of a Gi-coupled receptor causes ventricular conduction delay and a lethal cardiomyopathy. Proc Natl Acad Sci U S A 97:4826-4831. CrossRef Medline

Rezai-Zadeh K, Yu S, Jiang Y, Laque A, Schwartzenburg C, Morrison CD, Derbenev AV, Zsombok A, Münzberg H (2014) Leptin receptor neu- 
rons in the dorsomedial hypothalamus are key regulators of energy expenditure and body weight, but not food intake. Mol Metab 3:681-693. CrossRef Medline

Robinson S, Todd TP, Pasternak AR, Luikart BW, Skelton PD, Urban DJ, Bucci DJ (2014) Chemogenetic silencing of neurons in retrosplenial cortex disrupts sensory preconditioning. J Neurosci 34:10982-10988. CrossRef Medline

Rossi M, Kim MS, Morgan DG, Small CJ, Edwards CM, Sunter D, Abusnana S, Goldstone AP, Russell SH, Stanley SA, Smith DM, YagaloffK, Ghatei MA, Bloom SR (1998) A C-terminal fragment of Agouti-related protein increases feeding and antagonizes the effect of alpha-melanocyte stimulating hormone in vivo. Endocrinology 139:4428-4431. CrossRef Medline

Roth BL (2016) DREADDs for neuroscientists. Neuron 89:683-694. CrossRef Medline

Sachs BD, Ni JR, Caron MG (2015) Brain 5-HT deficiency increases stress vulnerability and impairs antidepressant responses following psychosocial stress. Proc Natl Acad Sci U S A 112:2557-2562. CrossRef Medline

Scofield MD, Boger HA, Smith RJ, Li H, Haydon PG, Kalivas PW (2015) Gq-DREADD selectively initiates glial glutamate release and inhibits cueinduced cocaine seeking. Biol Psychiatry 78:441-451. CrossRef Medline

Semjonous NM, Smith KL, Parkinson JR, Gunner DJ, Liu YL, Murphy KG, Ghatei MA, Bloom SR, Small CJ (2009) Coordinated changes in energy intake and expenditure following hypothalamic administration of neuropeptides involved in energy balance. Int J Obes (Lond) 33:775-785. CrossRef Medline

Sengupta A, Winters B, Bagley EE, McNally GP (2016) Disrupted prediction error links excessive amygdala activation to excessive fear. J Neurosci 36:385-395. CrossRef Medline

Silva BA, Mattucci C, Krzywkowski P, Murana E, Illarionova A, Grinevich V, Canteras NS, Ragozzino D, Gross CT (2013) Independent hypothalamic circuits for social and predator fear. Nat Neurosci 16:1731-1733. CrossRef Medline

Simonds SE, Pryor JT, Ravussin E, Greenway FL, Dileone R, Allen AM, Bassi J, Elmquist JK, Keogh JM, Henning E, Myers MG Jr, Licinio J, Brown RD, Enriori PJ, O'Rahilly S, Sternson SM, Grove KL, Spanswick DC, Farooqi IS, Cowley MA (2014) Leptin mediates the increase in blood pressure associated with obesity. Cell 159:1404-1416. CrossRef Medline

Siuda ER, Al-Hasani R, McCall JG, Bhatti DL, Bruchas MR (2016) Chemogenetic and optogenetic activation of Galphas signaling in the basolateral amygdala induces acute and social anxiety-like states. Neuropsychopharmacology 41:2011-2023. CrossRef Medline

Soudais C, Laplace-Builhe C, Kissa K, Kremer EJ (2001) Preferential transduction of neurons by canine adenovirus vectors and their efficient retrograde transport in vivo. FASEB J 15:2283-2285. Medline

Soumier A, Sibille E (2014) Opposing effects of acute versus chronic blockade of frontal cortex somatostatin-positive inhibitory neurons on behavioral emotionality in mice. Neuropsychopharmacology 39:2252-2262. CrossRef Medline

Stachniak TJ, Ghosh A, Sternson SM (2014) Chemogenetic synaptic silencing of neural circuits localizes a hypothalamus->midbrain pathway for feeding behavior. Neuron 82:797-808. CrossRef Medline

Stanley SA, Kelly L, Latcha KN, Schmidt SF, Yu X, Nectow AR, Sauer J, Dyke JP, Dordick JS, Friedman JM (2016) Bidirectional electromagnetic control of the hypothalamus regulates feeding and metabolism. Nature 531: 647-650. CrossRef Medline

Steculorum SM, Ruud J, Karakasilioti I, Backes H, Engström Ruud L, Timper K, Hess ME, Tsaousidou E, Mauer J, Vogt MC, Paeger L, Bremser S, Klein AC, Morgan DA, Frommolt P, Brinkkötter PT, Hammerschmidt P, Benzing T, Rahmouni K, Wunderlich FT et al. (2016) AgRP neurons control systemic insulin sensitivity via myostatin expression in brown adipose tissue. Cell 165:125-138. CrossRef Medline

Sternson SM, Roth BL (2014) Chemogenetic tools to interrogate brain functions. Annu Rev Neurosci 37:387-407. CrossRef Medline

Strobel SA (1998) Ribozyme chemogenetics. Biopolymers 48:65-81. CrossRef Medline

Sutton AK, Pei H, Burnett KH, Myers MG Jr, Rhodes CJ, Olson DP (2014) Control of food intake and energy expenditure by Nos1 neurons of the paraventricular hypothalamus. J Neurosci 34:15306-15318. CrossRef Medline

Takahashi KA, Cone RD (2005) Fasting induces a large, leptin-dependent increase in the intrinsic action potential frequency of orexigenic arcuate nucleus neuropeptide Y/Agouti-related protein neurons. Endocrinology 146:1043-1047. CrossRef Medline

Teissier A, Chemiakine A, Inbar B, Bagchi S, Ray RS, Palmiter RD, Dymecki SM, Moore H, Ansorge MS (2015) Activity of raphe serotonergic neurons controls emotional behaviors. Cell Rep 13:1965-1976. CrossRef Medline

Toda C, Kim JD, Impellizzeri D, Cuzzocrea S, Liu ZW, Diano S (2016) UCP2 regulates mitochondrial fission and ventromedial nucleus control of glucose responsiveness. Cell 164:872-883. CrossRef Medline

Urban DJ, Zhu H, Marcinkiewcz CA, Michaelides M, Oshibuchi H, Rhea D, Aryal DK, Farrell MS, Lowery-Gionta E, Olsen RH, Wetsel WC, Kash TL, Hurd YL, Tecott LH, Roth BL (2016) Elucidation of the behavioral program and neuronal network encoded by dorsal raphe serotonergic neurons. Neuropsychopharmacology 41:1404-1415. CrossRef Medline

Vardy E, Robinson JE, Li C, Olsen RH, DiBerto JF, Giguere PM, Sassano FM, Huang XP, Zhu H, Urban DJ, White KL, Rittiner JE, Crowley NA, Pleil KE, Mazzone CM, Mosier PD, Song J, Kash TL, Malanga CJ, Krashes M) et al. (2015) A new DREADD facilitates the multiplexed chemogenetic interrogation of behavior. Neuron 86:936-946. CrossRef Medline

Vazey EM, Aston-Jones G (2014) Designer receptor manipulations reveal a role of the locus coeruleus noradrenergic system in isoflurane general anesthesia. Proc Natl Acad Sci U S A 111:3859-3864. CrossRef Medline

Wang XF, Liu JJ, Xia J, Liu J, Mirabella V, Pang ZP (2015) Endogenous glucagon-like peptide-1 suppresses high-fat food intake by reducing synaptic drive onto mesolimbic dopamine neurons. Cell Rep 12:726-733. CrossRef Medline

Warthen DM, Lambeth PS, Ottolini M, Shi Y, Barker BS, Gaykema RP, Newmyer BA, Joy-Gaba J, Ohmura Y, Perez-Reyes E, Güler AD, Patel MK, Scott MM (2016) Activation of pyramidal neurons in mouse medial prefrontal cortex enhances food-seeking behavior while reducing impulsivity in the absence of an effect on food intake. Front Behav Neurosci 10:63. Medline

Wei D, Lee D, Cox CD, Karsten CA, Peñagarikano O, Geschwind DH, Gall CM, Piomelli D (2015) Endocannabinoid signaling mediates oxytocindriven social reward. Proc Natl Acad Sci U S A 112:14084-14089. CrossRef Medline

Wheeler MA, Smith CJ, Ottolini M, Barker BS, Purohit AM, Grippo RM, Gaykema RP, Spano AJ, Beenhakker MP, Kucenas S, Patel MK, Deppmann CD, Güler AD (2016) Genetically targeted magnetic control of the nervous system. Nat Neurosci 19:756-761. CrossRef Medline

Xu AW, Kaelin CB, Morton GJ, Ogimoto K, Stanhope K, Graham J, Baskin DG, Havel P, Schwartz MW, Barsh GS (2005) Effects of hypothalamic neurodegeneration on energy balance. PLoS Biol 3:e415. CrossRef Medline

Yagi H, Tan W, Dillenburg-Pilla P, Armando S, Amornphimoltham P, Simaan M, Weigert R, Molinolo AA, Bouvier M, Gutkind JS (2011) A synthetic biology approach reveals a CXCR4-G13-Rho signaling axis driving transendothelial migration of metastatic breast cancer cells. Sci Signal 4:ra60. CrossRef Medline

Yaswen L, Diehl N, Brennan MB, Hochgeschwender U (1999) Obesity in the mouse model of pro-opiomelanocortin deficiency responds to peripheral melanocortin. Nat Med 5:1066-1070. CrossRef Medline

Yau JO, McNally GP (2015) Pharmacogenetic excitation of dorsomedial prefrontal cortex restores fear prediction error. J Neurosci 35:74-83. CrossRef Medline

Yiu AP, Mercaldo V, Yan C, Richards B, Rashid AJ, Hsiang HL, Pressey J, Mahadevan V, Tran MM, Kushner SA, Woodin MA, Frankland PW, Josselyn SA (2014) Neurons are recruited to a memory trace based on relative neuronal excitability immediately before training. Neuron 83: 722-735. CrossRef Medline

You IJ, Wright SR, Garcia-Garcia AL, Tapper AR, Gardner PD, Koob GF, David Leonardo E, Bohn LM, Wee S (2016) 5-HT1A autoreceptors in the dorsal raphe nucleus convey vulnerability to compulsive cocaine seeking. Neuropsychopharmacology 41:1210-1222. CrossRef Medline

Yuan P, Grutzendler J (2016) Attenuation of $\beta$-amyloid deposition and neurotoxicity by chemogenetic modulation of neural activity. J Neurosci 36:632-641. CrossRef Medline

Zemelman BV, Nesnas N, Lee GA, Miesenbock G (2003) Photochemical gating of heterologous ion channels: remote control over genetically designated populations of neurons. Proc Natl Acad Sci U S A 100:1352-1357. CrossRef Medline 
Zhan C, Zhou J, Feng Q, Zhang JE, Lin S, Bao J, Wu P, Luo M (2013) Acute and long-term suppression of feeding behavior by POMC neurons in the brainstem and hypothalamus, respectively. J Neurosci 33:3624-3632. CrossRef Medline

Zhong P, Liu X, Zhang Z, Hu Y, Liu SJ, Lezama-Ruiz M, Joksimovic M, Liu QS (2014) Cyclin-dependent kinase 5 in the ventral tegmental area regulates depression-related behaviors. J Neurosci 34:6352-6366. CrossRef Medline

Zhu H, Pleil KE, Urban DJ, Moy SS, Kash TL, Roth BL (2014) Chemogenetic inactivation of ventral hippocampal glutamatergic neurons disrupts consolidation of contextual fear memory. Neuropsychopharmacology 39: 1880-1892. CrossRef Medline
Zhu H, Aryal DK, Olsen RH, Urban DJ, Swearingen A, Forbes S, Roth BL, Hochgeschwender U (2016) Cre dependent DREADD (designer receptors exclusively activated by designer drugs) mice [published online ahead of print May 19, 2016]. Genesis. CrossRef

Zimmermann KS, Yamin JA, Rainnie DG, Ressler KJ, Gourley SL (2015) Connections of the mouse orbitofrontal cortex and regulation of goaldirected action selection by brain-derived neurotrophic factor. Biol Psychiatry pii:S0006-3223(15)00956-7. CrossRef Medline

Zou D, Chen L, Deng D, Jiang D, Dong F, McSweeney C, Zhou Y, Liu L, Chen G, Wu Y, Mao Y (2016) DREADD in parvalbumin interneurons of the dentate gyrus modulates anxiety, social interaction and memory extinction. Curr Mol Med 16:91-102. CrossRef Medline 